\title{
Küresel Kentlerin Anlamsal İnşası: Web Sayfaları Üzerinden Toplumsal Göstergebilimsel Bir Analiz
}

*

\author{
Orçun Çobangil ${ }^{1}$ \\ ORCID: 0000-0001-8474-8646
}

Öz

Küreselleşme süreci ile hâkim hale gelen Neoliberal ideoloji içerisindeki postfordist üretim rejimiyle birlikte yaşanan dönüşümler, kentleri küresel ile ilişkili olarak doğrudan önemli bir aktör konumuna getirirken, diyalektik bir ilişki içerisinde hem kentlerden güç almakta hem de kentleri dönüştürmektedir. Bu bă̆lamda bu çalışma, bu ilişki çerçevesinde dönüşen/dönüştürülen kentlere ilişkin harekete geçirilen toplumsal göstergeleri ve sembolik anlam inşalarını inceleme amacını taşımaktadır. Bunun için, öncelikle küresel kentin anlamı ve işlevleri üzerine bir giriş yapuldıktan sonra, küresel kentlere ilişkin göstergeleri incelemek için kullanılabilecek toplumsal göstergebilim yaklaşımı tarihsel ve kuramsal çerçeve içinde ele alınacak ve literatürden örnek çalışmalar ile işlevsellikleri değgerlendirilecektir. Bu çalışmalarla ilişkili olarak, postmodern kent tahayyülleri ve kentlerin markalaşma süreçlerine değinilerek, göstergelerin ideolojik arka planı incelenecektir. Daha sonra, seçilmiş küresel kent örnekleri üzerinden kentlerin resmi web sayfalarında kullanılan kentlerin küresel gücüne ilişkin yazll temsiller toplumsal göstergebilimsel bir bağlamda ele alınarak, seçilen göstergelerin küresel kentin anlamsal inşasında nasıl rol oynadıkları, eleştirel bir epistemoloji içerisinde değerlendirilecektir.

Anahtar Kelimeler: toplumsal göstergebilim, küresel kent, marka kent, postmodern kent, kent kültürü.

\footnotetext{
${ }^{1}$ Arş. Gör., Dokuz Eylül Üniversitesi, E-mail: orcun.cobangil@deu.edu.tr idealkent @ Kent Araştırmaları Dergisi (Journal of Urban Studies) 


\title{
Semantic Construction of Global Cities: A Social Semiotics Analysis on Web Pages
}

\author{
Orçun Çobangil ${ }^{2}$ \\ ORCID: 0000-0001-8474-8646
}

\begin{abstract}
The transitions experienced with the post-fordist regime of production within the neoliberal ideology, which have become dominant with the globalization process, both get power from cities and transform them in a dialectical relationship while making cities important actors in relation to the global stage. In this context, this study aims to examine mobilized social indicators and symbolic meaning constructions related to transforming/transformed cities within the framework of this relationship. For this purpose, after an introduction on the meaning and functions of being global city, the social semiotics approach that can be used to examine the indicators related to the global cities will be discussed within the historical and theoretical framework at first. Then relevant literature, case studies and their functionality will be evaluated. In relation to these studies, the ideological background of the indicators will be examined by addressing the postmodern urban imaginations and the branding of cities. Afterwards, the written representations of selected global cities regarding to their global power used on the official websites will be addressed in a social semiotics context and the way the selected indicators play a role in semantic construction of being a global city will be evaluated in a critical epistemology.
\end{abstract}

Keywords: social semiotics, global city, city brand, postmodern city, urban culture.

${ }^{2}$ R. A., Dokuz Eylül University, E-mail: orcun.cobangil@deu.edu.tr

idealkent @ C Kent Araştırmaları Dergisi (Journal of Urban Studies)

http://idealkentdergisi.com

Geliş Tarihi Received Date: 20.05.2020 Kabul Tarihi Accepted Date: 14.12.2020 


\section{Giriş}

(...)Küresel kent mi olmak istiyorsunuz? Yetenekleri çekmeyi? Ticareti geliştirmeyi? Kentinizin beşerî sermayesini arttırmayı? Canlı ve kapsayıcı toplulukları teşvik etmeyi? Yabancı sermayeyi kentinize çekmeyi? Nüfusunuzun yeteneklerini tam kapasite ile kullanmayı? Turizmi arttırmayı?(...) (LUCIDE Kentsel Mekânlarda Çok Dillilik Tanıtım Broşürü).

Bir milyon nüfuslu bir kentin küresel kent sıralamasında ilk 10 içerisinde yer alması çok havalı bir şey. New York ile aynııı. Düşünsenize.(Naheed Nenshi, Calgary Belediye Başkanı). (Toneguzzi, 2013).

Eğer küresel kent olmak istiyorsanız, küresel kent gibi davranmalı ve küresel kentlerin yaptıklarını yapmalısınız.

(Lori Healey, Chicago Özel Kalem Müdürü). (ABC7 News, 2012).

Yukarıda yer verilen küresel (global) kent olmanın önemine dikkat çeken alıntılardan da görüldüğ̈̈ gibi, günümüzde küresel kent olmak, kazandırdığı olanaklar bakımından kentler için arzu edilen bir statüdür ama aynı zamanda belirli kurallara göre kent politikası oluşturmayı da gerekli kılmaktadır. Bu durum, küresel kent göstergelerine göre kentler arasında hiyerarşiler inşa etmektedir. Özellikle metropoliten bölgeler arasında bir pazarlama taktiği olarak küresel kent olma isteği bulunmakta, hatta bazı kentlerin salt küresel kent etiketi alabilmeleri için oluşturulmuş ölçekler nedeniyle küresel kent teriminin analitik gücünün muğlaklaştırıldığı ifade edilmektedir (Gottdiener, Budd ve Lehtovuori, 2016, s. 43-44). Böylelikle küresel kent teriminin kendisi başlı başına belirli kentsel formasyonları tanımlayan nötr değerde bir ifade olmanın ötesinde, belirli etiketler ve göstergeler bütünü olarak sunulmaktadır. Bu biçimde ele alınmasıyla küresel kent kavramı, küreselleşen ekonomide ve ilişkili neoliberal rejim altında kentsel mekânı dönüştürmede kente ilişkin karar alıcıları yönlendiren hâkim söylem olmaktadır (Öktem, 2016). Bu söylem altında kentlerin küresel ekonomideki konumlarına göre aralarında güç ve prestij yönünden hiyerarşiler oluşturulmakta (Alderson ve Beckfield, 2004), neoliberal politikalar tarafından kentlerin bu hiyerarşilerdeki başarılı örneklere göre dönüştürülmeleri özendirilmektedir.

Küresel kenti ele alan sosyal bilimsel bilgiyi, küreselleşmenin doğuşuyla eşzamanlı olarak, 1980'lerde başlatmak mümkündür. Küresel kent çalışmaları, özellikle kapitalizmin gelişmesi, sermaye birikimi ve bu bağlamda kentlerin küresel ilişkiler ağında finans merkezi olma ve çok uluslu firmalara ev 
sahipliği yapma niteliklerini ele almış dönemin Marksist kentleşme literatüründeki çalışmalarının etkisiyle ortaya çıkmıştır (Brenner ve Keil, 2016, s. 670672). Bu literatür, kentsel mekanlara ilişkin epistemolojisini sadece ulus devlet üzerinden değil, ulus devletleri de aşan sermaye hareketliliği üzerinden inşa ettiği için, küresel kent çalışmalarına yönelik verimli bir zemin sunmuş, aynı zamanda küresel kent çalışmalarının öncelikle ekonomik faktörlere odaklanmasına yol açmıştır. Örneğin, küresel kentlerin oluşumunu ilk olarak ele alanlardan Friedmann ${ }^{3}$ (1986, s. 69-73) kentlerin küresel sermayeye eklemlenmelerinde tarihsel geçmişleri, ulus devlet politikaları ve kültürel faktörleri göz önüne alsa da, süreci anlamlandırmada en açıklayıcı gücü ekonomik değişkenlerde bulduğunu belirtiyordu. Onun izinden giden ve küresel kent çalışmalarının en önemli teorisyenlerinden biri olan Sassen de (1991, s. 3-4), küresel kentleri kriz sonrası yeniden şekillenen ve paradoksal olarak hem küreselleşen hem de kutuplaşan dünyada; dünya ekonomisinin emir komuta noktaları, sanayi sektöründen ziyade finans ve özelleştirilmiş hizmet sektörü için kilit önemdeki yerler, özellikle hizmet sektörüne ilişkin inovasyon merkezleri ve bu kapsamda ortaya çıkan ürün ve hizmetler için önemli piyasa alanları olmaları üzerinden kavramsallaştırmıştır. Bu rolleri nedeniyle küresel kent statüsüne kavuşma, özellikle büyük kentler için, finans ve hizmet sektörleri kapsamında büyük ekonomik kaynakları kontrol etme imkânı sağladığından arzu edilmekte ve bu amaçla küresel kent listelerinde yukarı tırmanabilmek için rekabet teşvik edilmektedir. Sassen'i takip eden, Marksist literatürün de katkılarıyla gerçekleştirilen küresel kent çalışmaları ise kentlerin uluslararası sermaye ile ilişkilerine sadece kentlerin küresel kent olunca kazanacakları üzerinden bakmakla yetinmemekte, ayrıca sermayenin küresel olan kenti nasıl dönüştürdüğünü de mercek altına almaktadır. Bu kapsamda; firmaların emir komuta merkezi olma durumlarına göre kazananların ve kaybedenlerin olduğu küresel kent hiyerarşisinin oluşumu, kentsel mekanın küresel kent niteliği kapsamında yeniden yapılandırılmasında yaşanan mücadeleler (Örneğin; kent merkezinin küresel kente uygun olacak biçimde soylulaştırılması, sanayiden hizmet sektörüne geçiş ve küresel firma-

\footnotetext{
${ }^{3}$ Aslında Friedmann, "Küresel Kent (Global City) yerine "Dünya Kenti” (World City) terimini kullansa da günümüzde literatürde bu iki terim sıklıkla birbirlerinin yerine kullanılmaktadır. Yine de bu terimleri farklı tanımlayanlar da vardır. Buna göre küresel kent, özellikle 1980 sonrası küresel ekonomiye eklenme süreçleri ile öne çıkan kentleri (ki aslında Friedmann da dünya kenti ifadesini bu anlamda kullanmıştı), dünya kenti yüzlerce yıllık süreçte tarihsel olarak önemli olan kentleri ifade etmektedir. Bu çalışmada da "küresel kent" olarak 1980 sonrası küreselleşme örüntülerinin düğüm noktaları olan hâkim kentlere atıf yapılmaktadır. Konuya ilişkin detaylı bilgi için bkz. Chen, Orum ve Paulsen, 2018, s. 306-307.
} 
ların talepleri nedeniyle konut ve işletmelerin yerinden edilmesi, rant ilişkileri bağlamında emlak piyasası ve bunlara yönelik kentsel toplumsal hareketler) ve kentsel toplumsal dokunun geleneksel orta sınıfın erimesi nedeniyle oluşan ikili istihdam yapısı kapsamında dönüşümü, çalışmalar kapsamında ele alınmıştır (Brenner ve Keil, 2016, s. 670-672). Küresel kentler listeleri arasındaki hiyerarşik eşitsizliklerin yanında, kent içi eşitsizlik de özellikle enformel/marjinal sektörün büyümesi, artan soylulaştırma faaliyetleri ve evsizlerin artış göstermesi gibi olgularda ortaya çıkmaktadır (Sassen, 2000, s. 118-119).

Küresel kentleri Marksist terminoloji kapsamında alt yapının üst yapıyı belirlediği ekonomik faktörlerin önceliğinde açklayan yaklaşımların yanında Weberyan bir gelenekten gelen çalışmalarda kültürel endüstri ve hizmetlerin küresel kentleri fikirler ve değer merkezi haline getirme mekanizmaları üzerinde de durulmuştur. Bu çalışmalar küresel kent hiyerarşilerinde ekonomi ve kültüre göre yapılan siralamaların birbirine benzer ama tamamen aynı olmadıklarından hareketle kültürün bağımsız bir değişken olarak önemine işaret etmektedir. Medya kuruluşlarının ve bilgi ve teknoloji üretim merkezlerinin konumu, kentlerin kültürel güç bağlamında küreselliğini belirlemekte temel alınmaktadır (Abrahamson, 2014, s. 192, 201-202). Kültürel göstergelerin küresel kentleri tanımlamada gittikçe daha çok kullanılması, öncelikli olarak küresel kentler için en önemli rekabet alanlarından biri haline gelen turizm sektöründeki konumlarını güçlendirmelerinde kullanılmaktadır.

Küresel kent hiyerarşileri ile küreselleşen dünyada kentlerin etkileşimi ve kentsel değişimler hakkındaki konular; yukarıda işaret edilen neoliberal rejimin dengesiz büyüme eğilimleri sonucunda ortaya çıkan hızlı nüfus artışı ve kentleşme, yeni üretim ve teknoloji olanakları, çevre koruma, sürdürülebilirlik ve iklim değişikliği hakkındaki tartışmalar etrafında ele alınmakta, toplumsal eşitsizlik, yoksulluk ve kötüleşen çevre koşulları da bu tabloya eşlik etmektedir (LeGates ve Stout, 2016, s. 643, 648). Nitekim günümüzde en başarılı kentler olarak kurgulanan küresel kentlerden henüz yeni bahsedilmeye başlandığı bir dönemde bile Friedmann, küresel kentlerde hızla gelişen küresel sermayeye entegre formel sektör ile formel sektörde çalışanların ihtiyaç duyduğu hizmetleri karşılayan geniş bir informel sektör arasındaki ayrımın bu kentlerde önemli bir sorun alanı olduğunu belirtmişti. Ayrıca küresel kentlerin sermaye çekebilmek için büyük şirketlere tanıdıkları vergi muafiyetleri ve sübvansiyonlar kapsamında bütçelerini yapılandırmaları, informel sektörde geniş nüfuslarının barınma, ulaşım ve sağlık gibi temel gereksinim- 
lerini karşılamak için kaynaklarını kullanamadığı ve mali ve toplumsal krizlere yatkın oldukları anlamına geliyordu (Friedmann, 1986, s. 76-79). Bir diğer ifadeyle, başarılar kadar başarısızlıklar da küresel kentlerin toplumsal bir gerçeğiydi.

Küresel kentlerin oluşumunun gerçekleştiği sosyoekonomik koşullar olarak ele alınabilecek yukarıdaki arka planın yanı sıra, küresel kentlerin bir imge olarak anlamsal inşasında referans alınan (neoliberal) ideolojik arka plan da bulunmaktadır. Diğer bir ifadeyle, küresel kentlerin sunumu ve oluşturduğu episteme ile ontolojik gerçekliği farklı olabilmektedir. İşte bu çalışma, dayandıkları neoliberal ideolojinin en başarılı örnekleri olarak küresel kentlerin başvurdukları göstergeleri toplumsal göstergebilimsel bir metotla incelemek amacındadır. Nitekim Lefebvre'nin (2017, s. 73) de belirttiği gibi kentler bir metin olarak okunabilir ama bağlamdan yoksun bir okuma yapmak yeterli değildir. Toplumsal göstergebilim, ideolojik arka planı gösterge analizine dâhil etmesi nedeniyle önemlidir.

Çalışmanın amacı, toplumsal göstergebilim yöntemini kullanarak küresel kentlerin küreselliklerini nasıl kurguladıklarını, resmi/turistik web sayfalarındaki tanıtım metinleri üzerinden göstermektedir. Bu kapsamda çalışma, öncelikle günümüz küresel kentlerini bazı küresel kent listeleri üzerinden gösterecek, ardından küresel kentlerin web sayfalarının incelenmesinde kullanılacak toplumsal göstergebilimin gelişim sürecini ve kent ile ilişkili boyutlarını, postmodern tüketim kentine ilişkin tartışmalar etrafında kavramsal olarak ele alacaktır. Daha sonra konuya ilişkin literatür taraması ve metodoloji ortaya konularak, web sayfası metinlerinin analiz sonuçlarına yer verilecektir.

\section{Küresel Kent Listeleri}

Küresel kent çalışmalarının en önemli çıtılarından biri, küresel kentleri küresel önemleri kapsamında siralayan listelerdir (Alderson ve Beckfield, 2004; Godfrey ve Zhou, 1999; Leff ve Petersen, 2015). Küresel ekonomide kentler arası iş birliği ve rekabetin birlikte teşvik edildiği neoliberal rejim içerisinde bu listeler aslında bu süreçlerden hangi kentlerin galip çıtığını gösteren kentler arası hiyerarşileri çizmektedir. Çalışma konusunun evrenini oluşturan küresel kentlerin hangileri olduğuna işaret etmek için burada üç küresel kent listesi ele alınacaktır. 
Friedmann ve Sassen'in geleneğine dayanan, küresel kent çalışmalarında öne çıkan, küresel kent listelerini sistematikleştirmede öncü konumda sayılabilecek, bu nedenle burada ilk olarak değinilen Küreselleşme ve Dünya Kentleri Araştırma Ağı (GaWc) ekolü, özellikle Dünya Kent Ağları (WCN) başlığı altında firmalar ve ikameleri kapsamında hizmet sektörü üzerinden kentlerin birbirlerine kenetlenme derecelerini ele alarak çalışmaktadır (Chen, Orum ve Paulsen, 2018, s. 309). Küresel kent sıralamasında ele aldıkları faktörler, özellikle muhasebe, bankacllık ve hukuk gibi, küresel ekonomik entegrasyonla ilişkili gelişmiş hizmet sektörü kapsamında kentler arası ilişkilerin yoğunluğudur. Dolayısıyla çalışmaları kültürel ve politik boyutlardan ziyade ekonomik ilişkilere odaklıdır. Bu boyut üzerinden iki yılda bir oluşturdukları kent listeleri, küresel ekonomiye bağlanma derecelerine göre sirasiyla alpha, beta, gamma, yüksek yeterlik ve yeterlik başlıkları altında gruplandırılır. Gruplar da kendi aralarında önem derecelerine göre alt gruplara ayrılmaktadır. 2018 yılına ait listenin küresel ekonomiye en çok entegre olan kentleri gösterdiği alpha bölümü, alt kategorilerdeki kentler arasındaki hiyerarşi de soldan sağa doğru olacak şekilde, Tablo 1'de gösterilmektedir.

Tablo 1. Dünya Kentleri Araştırma Ağı (GaWC) 2018 Alpha Kentler Listesi

\begin{tabular}{ll}
\hline Alpha ++ & Londra, New York \\
\hline Alpha + & Hong Kong, Pekin, Singapur, Şangay, Sydney, Paris, Dubai, Tokyo \\
\hline Alpha & Milano, Chicago, Moskova, Toronto, Sao Paulo, Frankfurt, Los Angeles, Madrid, Meksiko, \\
& Kuala Lumpur, Seul, Jakarta, Mumbai, Miami, Brüksel, Taipei, Guangzhou, Buenos Aires, \\
& Zürih, Varşova, İstanbul, Bangkok, Melbourne \\
\hline Alpha - & $\begin{array}{l}\text { Amsterdam, Stockholm, San Francisco, New Delhi, Santiago, Johannesburg, Dublin, Vi- } \\
\text { yana, Montreal, Lizbon, Barselona, Lüksemburg, Bogota, Manila, Washington DC, Prag, } \\
\text { Münih, Roma, Riyad, Budapeşte, Houston, Shenzhen }\end{array}$ \\
\hline
\end{tabular}

Kaynak: GaWc, 2018.

Sadece ekonomik entegrasyon ve güce odaklanmayan küresel kent listeleri de bulunmaktadır. Listelerini oluştururken daha çeşitli faktörlerden yararlandıkları ve bu çalışmanın yapıldığı zamanda güncel olarak yenilendikleri için burada iki listeye daha yer verilecektir: Kearney 2019 Küresel Kentler Raporu, dünyanın en iyi performans gösteren kentleri olarak işaretlediği küresel kentleri; şirket aktiviteleri, beşerî sermaye, bilgi mübadelesi, kültürel deneyim ve politik ilgi unsurlarını dikkate alarak sıralamaktadır. Bir başka örnek olarak, Mori Memorial Foundation'ın 2019 Küresel Güçlü Kent Endeksi gösterilebilir. Bu liste de kentlerin ekonomi, araştırma/geliştirme, kültürel etkileşim, yaşanabilirlik, çevre ve erişilebilirlik alanlarındaki skorlarına göre hazırlanmıştır. Her iki listeden küresel kent niteliğine sahip ilk 20 kent Tablo 2 'de gösterilmektedir. 
Tablo 2. 2019 Küresel Güçlü Kent Endeksi ve 2019 Küresel Kentler Raporu Listelerine Göre İk 20 Kent

\begin{tabular}{|c|c|c|}
\hline Siralama & 2019 Küresel Güçlü Kent Endeksi & 2019 Küresel Kentler Raporu \\
\hline 1 & Londra & New York \\
\hline 2 & New York & Londra \\
\hline 3 & Tokyo & Paris \\
\hline 4 & Paris & Tokyo \\
\hline 5 & Singapur & Hong Kong \\
\hline 6 & Amsterdam & Singapur \\
\hline 7 & Seul & Los Angeles \\
\hline 8 & Berlin & Chicago \\
\hline 9 & Hong Kong & Pekin \\
\hline 10 & Sydney & Washington DC. \\
\hline 11 & Melbourne & Sydney \\
\hline 12 & Los Angeles & Brüksel \\
\hline 13 & Madrid & Seul \\
\hline 14 & Stockholm & Berlin \\
\hline 15 & Zürih & Madrid \\
\hline 16 & Toronto & Melbourne \\
\hline 17 & Frankfurt & Toronto \\
\hline 18 & San Francisco & Moskova \\
\hline 19 & Dubai & Şangay \\
\hline 20 & Kopenhag & Amsterdam \\
\hline
\end{tabular}

Kaynak: Mori Memorial Foundation, 2019 ve Kearney, 2019.

Kullanılan değişkenlere göre listelerde kentler arası sıralamalar farklılaşsa bile, Sassen'in çalışmasında (1991) üç temel küresel kent olarak gösterdiği New York, Londra ve Tokyo, Tablo 1 ve 2'de görüldüğü gibi güncel olarak bu niteliklerini korumaktadır. Paris, Singapur ve Hong Kong da benzer olarak siralamalarda zirvede yer almaktadır.

Ekonomi ve kültür arasındaki bağlantılar birbirlerinden ayrı değildir, çalışmanın ilerisinde ikisi arasındaki ilişkilerden marka kentler bağlamında bahsedilecektir. Küresel kent listelerine benzer şekilde, ama ekonomi yerine kültürel ve tanıtım odaklı faktörlere dayanarak hazırlanan marka kent listeleri de, küresel kent listeleri ile benzer bir biçimde kentler arası hiyerarşiler oluşturmaktadır.

\section{Toplumsal Göstergebilim: Kaynakları ve Kent Göstergebiliminde Kullanım Olanaklanı}

Bu bölümde özellikle Gottdiener'ın çalışmaları üzerinden toplumsal göstergebilim ve kent göstergebiliminde kullanım olanakları gösterilerek, çalışmanın metodolojisinde kullanılacak olan göstergebilim modelinin kavramsal gelişimi ortaya konulmuştur. 
Toplumsal göstergebilim; dizimsel (artsüremli) ve dizisel (eşsüremli) düzene dayalı anlatım dizgelerini, bunların kültüre bağlı alternatif açlımları kapsamında, ideolojiyi de eklemleyecek şekilde ele alarak inceleyen, yapısal göstergebilimin eleştirisi üzerine inşa edilmiş göstergebilimsel inceleme biçimi olarak tanımlanabilir (Gottdiener, 2005, s. 65). Toplumsal göstergebilime göre, Saussurecü klasik yapısal göstergebilimin belirttiğinin aksine, sadece dil değil bütün kültürel olgular dil gibi anlamlandırma dizgeleri içerir ve ayrıca simgesel etkileşimcilerin iddia ettiğinin aksine bu biçimde ortaya çıkan anlamlandırma süreçleri de iletişim edimi özelliği göstermek zorunda değildir. İdeolojik değerler de çözümlemelere göstergenin biçiminin yanında içerik tözü kapsamında dâhil edilmektedir ki bu töz genellikle kapitalist sermaye birikimine bağlı tüketim ideolojisi olmaktadır.

Toplumsal göstergebilimin öncüllerinden Gottdiener'in, kendi toplumsal göstergebilim yaklaşımını hangi gelenekler üzerinden inşa ettiğini incelemek, toplumsal göstergebiliminin göstergebilim literatüründeki konumunu ve amacını belirtebilir. Gottdiener, toplumsal göstergebilim yaklaşımını oluştururken dört temel yaklaşımdan faydalanmıştır (Gottdiener, 2005, s. 15-47). İlk olarak, Saussure'ün gösterge ve gösterilen üzerinden dizimsel ve dizinsel olarak ele aldığı yapısal göstergebilim yöntemi, her ne kadar Gottdiener tarafından sadece dilin kendi yapısına odaklandığı için yetersiz bulunsa da yine de en temel nokta olacaktır. Saussure'ün izinden giden, yani dil üzerine odaklanan ama göstergelerin çokanlamlılığ üzerinden söylen (mit) analizi yaparak kültürel boyutu göstergebilim analizine ekleyen Barthes ise, gösterge sistemlerindeki yan anlamların söylene dönüşerek hâkim kültüre göre temel anlamdan nasıl da daha önemli hale getirildiğini ve bunların ideolojik anlamlarının nasıl gizlendiğini incelemiştir. (Barthes, 2018) İkinci yaklaşım, göstergebilim için sadece dil çözümlemelerini yeterli bulmayan, kültürün bütününü de kapsayan, ayrıca gösterge sistemini gösterim-nesne-yorumlayan olarak üçlü ele alıp hem nesnel boyuta hem bilişsel anlamlandırmalara imkân tanıyan Pierce'in çalışmalarıdır. Üçüncü olarak, Saussure'ün yapısal metin çözümleyiciliğinin eleştirisini yapan Derrida gibi yapısökümcüler ve Baudrillard gibi postmodern düşünürlerden bahsedilebilir. Gottdiener, bu ekollerin metin odaklı yaklaşımları eleştirmesini kabul etse de yapısökümcüleri kültürel eleştiri konusunda zayıf bulmakta, Baudrillard'ın ise üstgerçeklik analizinde maddi göstergeleri ortadan kaldırmasın toplumsal göstergebilim için kabul etmemektedir. Nitekim Baudrillard için artık söz konusu olan üst/hipergerçekliktir; gerçeklikle ilişkisi kalmamış, asıl gösterilenlerinin ortadan 
kalktığı, yeniden canlandırmalar ile simülasyonların simulakralar oluşturduğu bir durumdur (Baudrillard, 2018). Son olarak Foucault'nun, bilginin düzenleyişinin iktidar ile olan ilişkisini ele alan yaklaşımı (Foucault, 2001) Gottdiener' in toplumsal göstergebilimine katkı vermiştir.

Yukarıdaki açıklamalarla benzer biçimde, Vannini (2007, s. 115-116), yapısal ve toplumsal göstergebilimi belirli özelliklerine göre karşılaştırmaktadır. Yapısal göstergebilim; gösterge sistemlerine ve simgelerine vurgu yapmakta, insanlar arası müzakereleri değil göstergelerin insanları nasıl yönettiğiyle ilgilenmekte, yapısal nedensellik varsaymakta ve ikili iletişim kodu öngörmektedir. Toplumsal göstergebilim ise; ikili iletişim kodunu eleştirmekte, göstergelerin içinde yer aldığı bağlamın önemini vurgulamakta, determinizme karşı olmakta ve göstergeler üzerindeki iktidar araçlarını incelemektedir. Bu nedenle Vannini için yapısal göstergebilim sadece dizisel ve dizimsel yapıya yönelmekle sınırlıken, toplumsal göstergebilim bu yapının üzerine toplumsal, politik (ideolojik) ilişki ve kavrayışlara odaklanır (Vannini, 2007, s. 125).

Toplumsal göstergebilim, görünenin arkasındaki toplumsal olgulara yönelik katkılarıyla, kentlere ilişkin anlam işaretleyicilerini sorgulayacak bir kentsel göstergebilim pratiği altında da ele alınabilir. Kentsel göstergebilim, kentlere ilişkin anlam göstergelerini kentlerinin toplumsal, kültürel ve fiziksel üretimi bağlamında çağrıştırdığı anlamlar ile birlikte ele alarak eleştirel kent çalışmalarına iki temel katkı sağlamaktadır: Öncelikle kendisi başlı başına bir gösterge olan kent ve kent içindeki göstergelerin çalışılması ile kentin çok katmanlı yüzünü ele alması ve ikinci olarak kentsel mekanın nötr görünümünün arkasında gizlenmiş, bu katmanlarındaki ideoloji ve politika yüklü mekanizmaları ortaya çıkarması. Özellikle kentsel mekânın neoliberalleşmesi ile birlikte kentlerin kültürel unsurlarının kentsel pazarlama ve kentler hiyerarşisinde yükselebilme için metalaştırıldığı dikkate alındığında, kentlerdeki tüketim imgelerine dayalı oluşturulan işaretleyici pratiklerin yani göstergelerin politik ekonomisini yapmak, toplumbilimsel bir kent göstergebilimi ile mümkün olabilir (Stahl, 2010, s. 918, 920). Çünkü bu tüketim alanları işaretlerin göstergebilimsel gücünden yararlanmakta, kaynaklarını kent mitlerinden (kentsel mekâna anlam veren hikâye ve söylemlerden), inovasyondan ve yaratıclıktan almaktadırlar (Stahl, 2010, s. 920). Tüm bu sürecin temel dayanağ1 ise, hâkim kentsel söylemin evrensel ve tümleyici kent algısına dayalı, kapitalist çatışma ve kriz durumunu gizleyen nötrleştirici kentsel epistemolojidir ki bu epistemolojiye dayalı neoliberal söylem, piyasa güdümlü kentsel dönüşümleri haklı kılan bir anlatı oluşturmaktadır (Brenner ve Schmid, 2015, s. 
158). Bu anlatının eleştirel bir biçimde ele alınması, özelikle insanların kentlere ilişkin bilgiyi edinme sürecinde ortaya çıkan eleştirel kentsel teori potansiyelindeki üç nokta nedeniyle önem kazanır: Kentsel elitler ve ideologlar tarafından kaçınılmaz bir biçimde sunulan kentsel bilginin niteliğini değerlendirmek, kentsel müştereklere kimlerin dâhil olabildiğini veya olamadığını değerlendirerek kenti demokratikleştirme imkânlarını açmak ve farklı kentsel uygulamalar için alternatif kentsel bilgi, pratik ve tahayyüller ortaya koymak (McFarlane, 2017, s. 178). Çünkü kentsel mekân ve kentsel mekâna ilişkin bilgiler, birbiriyle diyalektik bir ilişki içerisindedir.

Kentsel göstergebilimin konusunu ele alış biçimine (epistemolojisine) yönelik olarak, Lagopoulos, birbirlerini destekleyebilecek iki temel yol olduğunu belirtir; mekânın "doğrudan" bir metin gibi ele alınıp yorumlandığı, doğrudan yapılı çevre üzerine inceleme yapılabilir veya "dolaylı" olarak, dini, mitolojik, felsefi metinler, edebiyat, basın, sinema, resim ve benzeri toplumsal ürünler üzerinde bulunan mekânsal temsillerin analizi yapılabilir ("metindeki mekân") (Lagopoulos, 2019, s. 23). Gottdiener ve diğerleri ise dörtlü bir kentsel göstergebilim kategorisi oluşturmuşlardır: Kentte gerçekleşen rutin ve olaylara ilişkin ifadelerin incelenmesi, kentin belirli bölgelerindeki ayrı söylem, jest, mimik ve benzerlerinin incelenmesi, gösterilen ve gösteren arasındaki ilişkiyi belirten anlamların nasıl yan anlamlarla işlev gösterdiğini analiz eden kent dilinin incelenmesi ve kentteki yazıların (Duvar yazıları, panolar, tabelalar vs.) incelenmesi (Gottdiener, Hutchison ve Ryan, 2015, s. 98). Bu çalışmanın kentleri tanıtan web sayfalarındaki metinlerde kurgulanan mekân olgusunu yan anlamlariyla ele alma boyutu kapsamında, Lagopoulos'un ikinci Gottdiener ve diğerlerinin üçüncü sırada ele aldığ kentsek göstergebilim konularına dâhil edilebileceği belirtilebilir.

Kentsel göstergebilimin toplumsal göstergebilimsel bir biçime dönüştürülmesi, kenti veya kente ait alt unsurları çevreleyen ideolojik yapının da analize katılması ile mümkün olur. Örneğin Lagopoulos (2019), Selanik kent planını incelediği çalışmasında, sadece gösterilen ve gösterge unsurları üzerinden üretilen temel (dennotative) ve yan (connotative) anlamları analiz etmenin yeterli olamayacağını, planı hazırlayanların, onaylayanların ve kamuoyunun kararlarını şekillendiren ve bazen birbirleriyle çatışan modernizm ve milliyetçilik ideolojilerinden nasıl etkilendiğini göstermekle toplumsal göstergebilim seviyesinde analiz yapılabileceğini belirtmiştir Bu kapsamda Lagopoulos, tarih boyunca kentlerin göstergebilimsel anlamlarını şekillendiren; modernizm öncesi, modernist ve postmodernist olmak üzere üç temel aşama sunmuştur (Lagopoulos, 2019, s. 28-33). Nitekim kente ve kentsel tasarıma 
ilişkin teorilerde modernizm ve postmodernizme göre ayrım yapma literatürde hâkim konumdadır (Örneğin; Goodchild, 1990; Harvey, 2019; Hirt, 2009) ve postmodern kentsel imgelemler günümüzdeki küresel kentlere ilişkin göstergelerde ön plana çıkmaktadır.

\section{Kentsel Göstergebilimin İdeolojik Çerçevesi Olarak Postmodern Kentsel İmgelem ve Küresel Marka Kentler}

Neoliberalizmin etkisi altında günümüz kentlerinin birbirleriyle rekabet etmelerinin teşvik edildiği ve bu amaçla kültürün metalaştırıldığı tüketim odaklı kentsel epistemolojiye, yani postmodern aşamaya yukarıda işaret edilmişti. Postmodern aşamanın özellikleri, küresel kentlerin en başarılı örnekleri olduğu ideolojik çerçeveyi sunduğu ve bu ideolojik çerçevenin de toplumsal göstergebilim için önemi üzerinden hareketle, daha detaylı ortaya konulmalidir.

Sanayi sonrası kent aşamasına geçen ve hizmet sektörüne dayalı kentlerin birbiriyle rekabet etmesinde kentsel imajın oynadığı role değinen Harvey bu imajın oluşumunu, temel olarak kentlerin özgünlüğünü ortadan kaldırdığ için modernist işlevselciliğe karşı çıkan bireysel/popülist talepler ile tarihi eklektik bir biçimde kullanıma sokan nostalji politikalarına bağlı ortaya çıkan postmodern kentleşme örüntüleri üzerinden incelemektedir. Kitlesel birikim rejiminin esnek birikim rejimine dönüşmesi ve teknolojinin yardımıyla sermaye deviniminin artmasının iki önemli sonucu; hizmetlerde (Özellikle eğlence sektöründe) artış ve mal vehizmetlerin geçiciliği olgusudur. Bu nedenle bu sürecin yönetilerek kente yatırım ve beşerî kaynak çekilebilmesi, arzu, zevk ve fikirlerin yönlendirilebilmesine dayanmaktadır. Bunun da en temel yolları, reklam ve medya imajları aracılığıyla gösterge sisteminin ve kentsel imajların yaratılmasıdır (Harvey, 2019, s. 84-119, 318-320). Nitekim özellikle büyük kentlerin kentler arası rekabetteki konumları; hayat tarzları, yaşam olanakları ve yüksek kültür imkânları çerçevesinde uluslararası kültürel hegemonyadaki konumlarını sürdürmelerine bağlıdır (Harvey, 2016, s. 78). Harvey için tüm bu süreçler, kentler arası rekabetin politik stratejileri içerisinde yer alır ki bu stratejiler "kapitalizmin tarihsel dinamiğinin coğrafi bağlamda dışa vurulması" (2016, s. 28) üzerinden okunmalıdır.

Kentsel politik ekonomide kültürel üretim ve temsillerin önemini üzerine eğilen Zukin de kentsel imgenin, kültür endüstrisinin (Müzeler, kafeler, sanat eserler, kafeler, butikler, tarihi yapılar, eğlence ortamları vs.) rolüne bağlı olarak tüketimin organizasyon biçimi etrafında örgütlendiğine dikkat çekmekte; 
özellikle görsel yönü güçlü, özelleştirilmiş kültürlerin kentler arası rekabette kullanıldığını belirtmektedir (Zukin, 2000, s. viii-ix, 1-3). Resim, tasarım, inovasyon ve yaratıcı değerler üzerine inşa edilen kentsel imge, artık kentlerin temel ekonomik kaynakları arasındadır. Böylece kentlerin, kenti oluşturan geleneksel unsurların (arazi, sermaye ve emek) yanında kent yönetimlerinin ve özel sektörün ekonomik bir araç olarak kullandığı kültür endüstrisine dayalı sembolik ekonomi/dilden de oluştuğu belirtilmektedir. Kente ilişkin neyin istenilen neyin istenilmeyen olduğunu belirten bu sembolik dil, küresel kent statüsüne erişebilmek için de önem taşımaktadır. Müzeler, parklar, kent mimarisi, sanat yapıtları gibi kentsel unsurlar da bu bağlamda biçimlendirilir (Zukin, 2000, s. 7-23). Nitekim Zukin'e göre 21.Yüzyıl'da bu eğilimler daha da yoğunlaşmış, kentler için "otantik olma" niteliği ön plana çıkmıştır. Hem eskiye/tarihselliğe hem de şimdiye atıf yapan bir kavram olan otantiklik, kent imajı oluşturma bağlamında artık performanslara dayalı ve görsel bir biçimde ele alınır (Zukin, 2010, s. xii-xiii, 3).

Hem Harvey hem de Zukin'in açıklamalarından hareketle, kültürün özellikle görsel bir deneyim olarak kentler tarafından birbirleriyle rekabette kullanıldığını, kent vizyonlarının bu yaklaşıma göre şekillendirildiği belirtilebilir. Kent vizyonlarının bu biçimde oluşturulması da fordist modern sanayi kentinden postfordist sanayi sonrası post modern kente dönüşüm ile mümkün olmuştur. Bu nedenle küresel kent statüsü için en gerekli unsurlar, bilgi yoğun yüksek teknolojiye dayalı sektörler, ticaret ve finans merkezleri ve gelişmiş kültür endüstrisidir (Abrahamson, 2014, s. 76-81). Bu unsurlar, küresel kentlerin anlamsal inşasına etkide bulunan ideolojik çerçeveyi (göstergenin içerik biçimini) de oluşturmaktadır.

Tüketim odaklı kültür endüstrisi etrafında küresel rekabet içerisinde kentler, bu amaçla oluşturdukları kent vizyonunu kentlerini markalaştırarak ortaya koymaktadır (Dinnie, 2011, s. 3). Ticari ürün ve hizmetlere ait markalarının tanımladıkları ürün ve hizmetleri diğerlerinden ayırarak farklılıklarını ortaya koymaları gibi, kentlerin markaları da onların belirgin kılan ve onları öne çıkarıp diğer kentlerden ayıran göstergeleri kullanmaktadır. Yine de hâkim küresel kent imgesi, neoliberal postfordist birikim rejiminde ayn ideolojik çerçeveye (finans, profesyonel hizmetler ve tüketim odaklı kültür endüstrisi) dayandığı için, kentlerin markaları arasında da büyük ortaklıklar vardır. Nitekim Vanolo, farklı küresel kent etiketleri altında, aslında birbirlerini (özellikle başarılı örnekleri) taklit eden küresel kent imgelerinin dolaşımda olduğunu vurgulamaktadır (2017, s. 134). Bu imgeler arasındaki fark- 
lılık kentlere ait markaların/imgelerin/vizyonların işlevsel değerinden çok eklenmiş değerinde ortaya konulmaktadır. Markaların işlevselliği, kentsel mekânların iş ve barınma gibi klasik fonksiyonlarına vurgu yaparken, markaların eklenmiş değeri, yaratılan kent vizyonu ile kullanıcılar (kentte ikamet edenler veya turistler) arasında duygusal bir bağ yaratmaya çalışmaktadır. Kültürel çeşitlilik, kentsel görünüm, entegrasyon (farklı unsurların uyuşmas1), yaşanan kentsel deneyim ve bu deneyimlere ilişkin tanıklıkların insanlar arasında yayılması, algı ve inanç (kentin finansal gücüne duyulan inanç gibi); marka kentler arasındaki temel farklılıkları ve kentlerin ne kadar başarılı bir biçimde markalaştıklarını gösteren unsurlardır (Winfield-Pfefferkorn, 2005, s. 14-23). Bu unsurların başarılı bir biçimde kullanılabilmesi için, kentin tarihinin, kültür endüstrisinin ve yaşam kalitesinin reklamını yapabilmeleri ve marklarının tanımlayıcı ve ayırıcı olması gerekir (Winfield-Pfefferkorn, 2005).

Tablo 3. En İyi Markaya Sahip İlk 20 Kent Listesi (Saffron ve Resonance'a Göre)

\begin{tabular}{lll}
\hline Siralama & $\begin{array}{l}\text { 2019 Saffron Kent Marka } \\
\text { Barometresi }\end{array}$ & $\begin{array}{l}\text { Resonance 2019 Dünya'nun En İyi } \\
\text { Kentleri Listesi }\end{array}$ \\
\hline 1 & New York & Londra \\
\hline 2 & Londra & Paris \\
\hline 3 & Singapur & New York \\
\hline 5 & Hong Kong & Tokyo \\
\hline 6 & Amsterdam & Barselona \\
\hline 7 & Los Angeles & Moskova \\
\hline 8 & Chicago & Chicago \\
\hline 9 & Dubai & Singapur \\
\hline 10 & Boston & Dubai \\
\hline 11 & Washington DC & San Francisco \\
\hline 13 & Berlin & Madrid \\
\hline 14 & Madrid & Amsterdam \\
\hline 15 & San Francisco & Los Angeles \\
\hline 16 & Frankfurt & Roma \\
\hline 17 & Voronto & Boston \\
\hline 18 & Paris & San Jose \\
\hline 19 & Barselona & Toronto \\
\hline 20 & Kopenhag & Washington DC \\
\hline
\end{tabular}

Kaynak: Saffron, 2019 ve Resonance, 2018. 
Küresel kent sıralamaları olduğu gibi, kentler markalaşma durumlarına göre de sıralanmaktadırlar. Örneğin kentlerinin varlıklarına cazibe merkezlerine, iklim özelliklerine, altyapı/ulaşım olanaklarına, güvenlik ve genel ekonomik refah seviyelerine ve kentlere ilişkin söylenti ve geleneksel ve sosyal medyadaki kentlere ilişkin referansların sıklığına (buzz) göre oluşturulan 2019 Saffron Kent Marka Barometresi ile mekân, üretim, insanlar, refah ve tanıtım faktörlerine göre oluşturulan Resonance'ın 2019 Dünya'nın En İyi Kentleri sıralaması, yukarıda çizilen çerçeve içerisinde kentler arası hiyerarşiler oluşturmaktadır (bkz. Tablo 3). Bu listelerin küresel kent listeleriyle önemli benzerlikler taşıdığı görülmektedir. Londra, Paris, New York, Tokyo gibi hâkim küresel kentler aynı zamanda en iyi marka kentler olarak gösterilmektedir.

\section{Toplumsal Göstergebilimsel Yaklaşımıyla Kentlerin Web Sayfalarının İncelenmesi}

Bu bölümde kentlerin web sayfaların göstergebilimsel olarak inceleyen literatüre işaret edilerek, bu çalışmanın ilgili literatüre nasıl katkı sağlayabileceği ortaya konulmuştur.

Web sayfaları, herhangi bir ürün ve hizmet için olduğu gibi mekânlar için de imaj oluşturmada en önemli yerler haline gelmiştir. Kentler web sayfaları aracılığıyla genel olarak markalaştırmak istedikleri kimliklerine ilişkin özellikleri (logolar gibi), özellikle turistlere yönelik vaat ettikleri özellikleri (etkinlikler vb.) ve kent yönetimi ve planlaması hakkında bilgileri içerik olarak sunmaktadır. (Florek, 2011, s. 82-85). Bu türden web sayfalarının içeriğini analiz eden birçok çalışmaya rastlamak mümkündür. Örneğin Florek ve diğerlerinin çalışması (2006), Yeni Zelanda'daki kent meclislerinin resmî web sayfalarına, marka (Tasarım, logo, fotoğraflar, video, harita), marka davranışı (Haberler, planlar, etkinlikler vb.) ve marka iletişimi (Kent hakkında genel bilgiler) kategorileri altında içerik analizi yaparak kent markasının sunumunun nasıl gerçekleştiğini ortaya koymuşlardır. Míguez González'e (2011) ait çalışma da Galiçya/İspanya'nın yedi temel kentinin remi belediye ve turizm sayfaları üzerinden kent kimliklerinin nasıl farklılaştığını göstermektedir. $\mathrm{Bu}$ çalışmalarda temel amaç, kentlerin kendilerini nasıl markalaştırdıklarını betimlemek ve markalaşma için öneriler ortaya koymaktır. Markalaşma ve kentsel imaj konuları özelikle turizm sektörü bağlamında kentlerin tanıtılması ve betimlenmesi hakkında ele alınmaktadır. Örneğin Költringer ve Dic- 
kinger (2005), turizme ilişkin kentsel imaj konusunda, sadece resmî web sayfalarını inceleyen çalışmaların aksine blog sayfaları ve arama motorları üzerinden turistik mekânlar, aktiviteler, ulaşım, konaklama kategorilerine göre veri madenciliği yaparak markalaşmada temel örüntüleri bulmaya çalışmışlardır. Hatta web sayfaları sadece kentler için değil kırsal mekânların markalaştırılması bağlamında da ele alınmıştır (Boyne ve Hall, 2004). Bahsedilen çalışmaların ortak temel amacı, mekânların markalaşmasında web sayfalarının nasıl kullanılabileceğini göstermek ve söz konusu eksiklilere işaret etmektir. Bu çalışmalarda her ne kadar web sayfalarına içerik analizleri yapılsa da içeriklerin göstergebilimsel bir yaklaşımdan ziyade sadece betimsel bir biçimde ele alındığı görülmektedir. Yine de bu çalışmalar, web sayfalarının kentlere ilişkin anlamsal inşalarda ne kadar önemli olduklarını da göstermektedir.

Web sayfalarının içeriklerini hem genel olarak hem de özellikle kentlerin tanımı amacıyla göstergebilimsel olarak analiz eden çalışmalar ise çok daha azdır. Web sayfaları ile ilgili olarak etkili bilgi aktarımı için tasarım ögelerinin (site ara yüzü, navigasyon, efektif menü oluşturma vb.) nasıl kullanması gerektiğini gösteren araçsal çalışmalardan (Bolchini, Chatterji ve Speroni, 2009) web sayfalarının biçimi ile içerdiği verileri eşleştiren (Örneğin, bloglar diyalojik etkileşim alanı olarak, wiki sayfaları toplumsal inşacı olarak ve sosyal medya sayfaları simgesel etkileşimci olarak) göstergebilimsel çalışmalar (Warschauer ve Grimes, 2007) bulunmaktadır. Bu çalışmalar her ne kadar web sayfaları üzerine göstergebilimsel analiz yapılabileceğini işaret etse de daha betimsel kalmakta ve özellikle kent sayfalarına ilişkin eleştirel toplumsal göstergebilimsel bir yaklaşım çizmede gerekli çerçeveyi sunamamaktadır. Buna karşlık doğrudan kentlere ilişin olarak, Paganoni'nin (2012) Birleşik Krallık'taki 12 kent meclisi web sayfası üzerine yaptığı çalışması ise, bu sayfalardaki içeriklerin farklı toplumsal grupları ne kadar içerdiğini, toplumsal göstergebilimsel bir yaklaşım ile ele almaktadır. Paganoni'ye göre çalışmanın toplumsal göstergebilimsel boyutu, çalışmanın rekabet içerisindeki küresel kent kimliğinin oluşumunda farklı toplumsal grupları kapsayan kentsel imaj oluşturulmasını dikkate almış olmasıdır. Kent tarafından ulaşılmak istenen yerel-küresel kimliğe ilişkin kent meclisi web sayfalarının nasıl kapsayıcı olduğunun tespit edilmesi çalışmasının amacıdır. İdeolojik düzlemin eleştirisini içermediği için toplumsal göstergebilimsel nitelik taşımasa da göstergebilimsel olarak web sayfa düzeni ve metinlerde yer alan izotopi şemaları üzerinden Seul, Tokyo ve Pekin'in web sayfalarının kentlerin marka değeri aç1sından incelendiği bir çalışma da (Jeon ve Jeon, 2012), bu kentler hakkında 
bilgi, turizm, ekonomi ve yerel hizmetler kategorileri bağlamında veri sunmaktadır. Bahsedilen son iki çalışmanın asıl amacı, göstergebilimsel analiz sonrası eksikliklerin tespit edilip kentlerin marka değerinin güçlendirilmesidir.

Küresel kentlerin web sayfaların toplumsal göstergebilimsel olarak inceleyecek olan bu çalışma, her ne kadar yukarıda özetlenen literatürden bir ölçüde yararlanacak olsa da, temel amacı itibarıyla farklılaşmaktadır: Yukarıdaki çalışmaların temel amacı kentlerin marka değerlerinin gücünün tespiti/iyileştirilmesi üzerine odaklıyken, bu çalışmada seçilmiş küresel kentlerin web sayfalarında kullanılan metinlerin, hâkim küresel kent kimliği ile ilişkili olarak nasıl yapılandırıldığı üzerinde durularak literatüre katkı sağlanması hedeflenmektedir. Çünkü Web sayfalarındaki mesajların bilginin yayılmasındaki büyük önemine karşılık, buralardaki metinler üzerinde eleştirel göstergebilimsel çalışmaların sayısı yeterli seviyede değildir.

\section{Metodoloji}

Çalışmanın araştırma sorusu; hangi göstergeleri kullanarak küresel kentlerin kendilerini nasıl kurguladıkları ve toplumsal göstergebilimin bu süreci okumakta nasıl bir katkı sağlayabileceğidir. Buna göre metodolojik olarak şu konuların ortaya konulması gereklidir: Toplumsal göstergebilim nasıl metodolojik çerçeve olarak kullanılabilir ve buna göre nasıl analiz yapılabilir? Analiz yapılacak küresel kentler ve ilgili metinler nasıl seçilmelidir?

Küresel kentleri tanıtıcı metinlere yönelik içerik analizi için, ikinci bölümde ele alınmış olan Gottdiener'in toplumsal göstergebilimsel analizine ilişkin şema çalışmanın temel çerçevesi olacaktır. Bu şemaya göre bir gösterge, içerik (kodlanmamış/ genel ve kodlanmış/özel) ve anlatım (biçim ve töz) unsurlarından oluşmaktadır (Şekil 1). İçerik genel olarak kültür ve ideolojiye (neoliberal/postmodern değerler) karşılık gelmekte, anlatım ise içeriğe bağlı olarak göstergenin genel tasarım ilkelerini (biçim) ve içindeki maddi alt unsurları oluşturmaktadır (töz). Gottdiener, Peirce'in izinden giderek, bu şemanın metinlerin yanında gündelik yaşama ilişkin birçok nesne üzerinde (ev, araba, moda, alışveriş merkezleri, tema parklar, mimari unsurlar vb.) kullanılabileceğini belirmektedir (Gottdiener, 2005, s. 50-51). Bu çalışma bu çerçeveyi seçilmiş küresel kentlere ilişkin web sayfalarındaki metinler üzerinde kullanacaktır. 


$$
\begin{aligned}
\text { İçerik }=\frac{\text { Töz }}{\text { Biçim }}=\frac{\text { Kodlanmamış İdeoloji }}{\text { Kösterge: }}= \\
\text { Anlatım }=\frac{\text { Biçim }}{\text { Töz }}=\frac{\text { Biçimsel Ögeler İdeoloji }}{\text { Maddi nesneler, metin }}
\end{aligned}
$$

Şekil 1: Gottdiener'ın Toplumsal Göstergebilime Göre Göstergenin Ayrıştırılması Modeli (Gottdiener, 2005, s. 51).4

Şekil'1'e göre, öncelikle göstergelerin içerik boyutuna (ideoloji) yönelik olarak, postmodern kentsel tahayyüller ve küresel marka kent yaklaşımları, neoliberalizm ideolojisinin (içerik tözünün), küresel kentler için kodlanmış ideolojisini (içerik biçimini) oluşturmaktadır. Çalışmanın bu boyutu, yukarıda Lagopoulos'un belirttiği kentlerin göstergebilimsel anlamların şekillendiren postmodern aşamanın analizine karşılık gelmektedir.

Göstergenin anlatım boyutuna yönelik olarak, web sayfaları anlatım biçimini, küresel kentlerin web sayfalarında yer alan metinler üzerine yapılacak içerik analizi, Şekil 1'de görüldügü gibi anlatımın tözüne karşılık gelmektedir. Anlatım tözünü oluşturan metinlerin incelenmesi için ise göstergebilimsel izotopiden (isotopy (ing), isotopie (fr)) yararlanılacaktır. Göstergebilimsel izotopi, aslında Greimas'ın ortaya çıkardığı, Fransız yapısal göstergebilim okuluna ait bir kavramdır (Kourdis, 2012, s. 106-107). Temel olarak, bir metindeki anlamsal bütünlüğü sağlamak için benzer anlam şemalarına ait unsur ve özelliklerin metin boyunca tekrarlanmasını ifade eder. Bu çalışma, Şekil 1'deki şemaya anlatım tözünün incelenmesiyle entegre edilerek, klasik yapısalcı yaklaşımdan daha farklı ele alınacaktır. Yukarıda bahsedilen Jeon ve Jeon'un Seul, Tokyo ve Pekin'in web sayfalarını markalaşma bağlamında göstergebilimsel olarak analiz ettikleri çalışmaları için, Semprini'nin (1992, s. 110) çalışmalarından hareketle oluşturdukları izotopi şeması (2012, s. 981982), bu konuda iyi bir başlangıç noktası oluşturmaktadır (Şekil 2). Metinlerin incelenmesi, özellikle kullanılan kavramların Şekil 2 bağlamında işaret ettikleri anlam bakımından yan anlamsal boyutuyla da ele alınmış olacaktır. Buna göre, göstergeler görev, bilgi, proje ve öfori boyutlarına göre incelenecektir. Görev; gelecek odaklı vizyonları ve yenilikçiliği, bilgi; avantajları, işlevselliği,

\footnotetext{
$4 \mathrm{Bu}$ şema, Eco'nun mimarinin göstergebilimine ilişkin kullandığı Hjelmslev'in göstergeleri içerik ve dışavuruma göre töz ve biçimleri yönüyle ele alan yaklaşımının (Eco, 2019: 89), ideolojinin rolüne vurgu yapılmış hali olarak da okunabilir.
} 
proje; bireysel deneyimlere odaklanan keşifleri ve dönüşümleri, öfori; deneyimlere dayalı mutluluğa vurgu yapmaktadır. Genel olarak görev ve bilgi kent düzeyinde toplumsal, proje ve öfori bireysel düzeyde anlamları, sırasıyla gelecek ve şimdi odaklı olarak yansıtmaktadır Ayrıca bu şema ile dizisel ve dizimsel olarak, yani göstergelerin nasıl birlikte ve hangi yan anlamlara atıf yapacak şekilde kullanıldığı da gösterilmiş olunmaktadır.

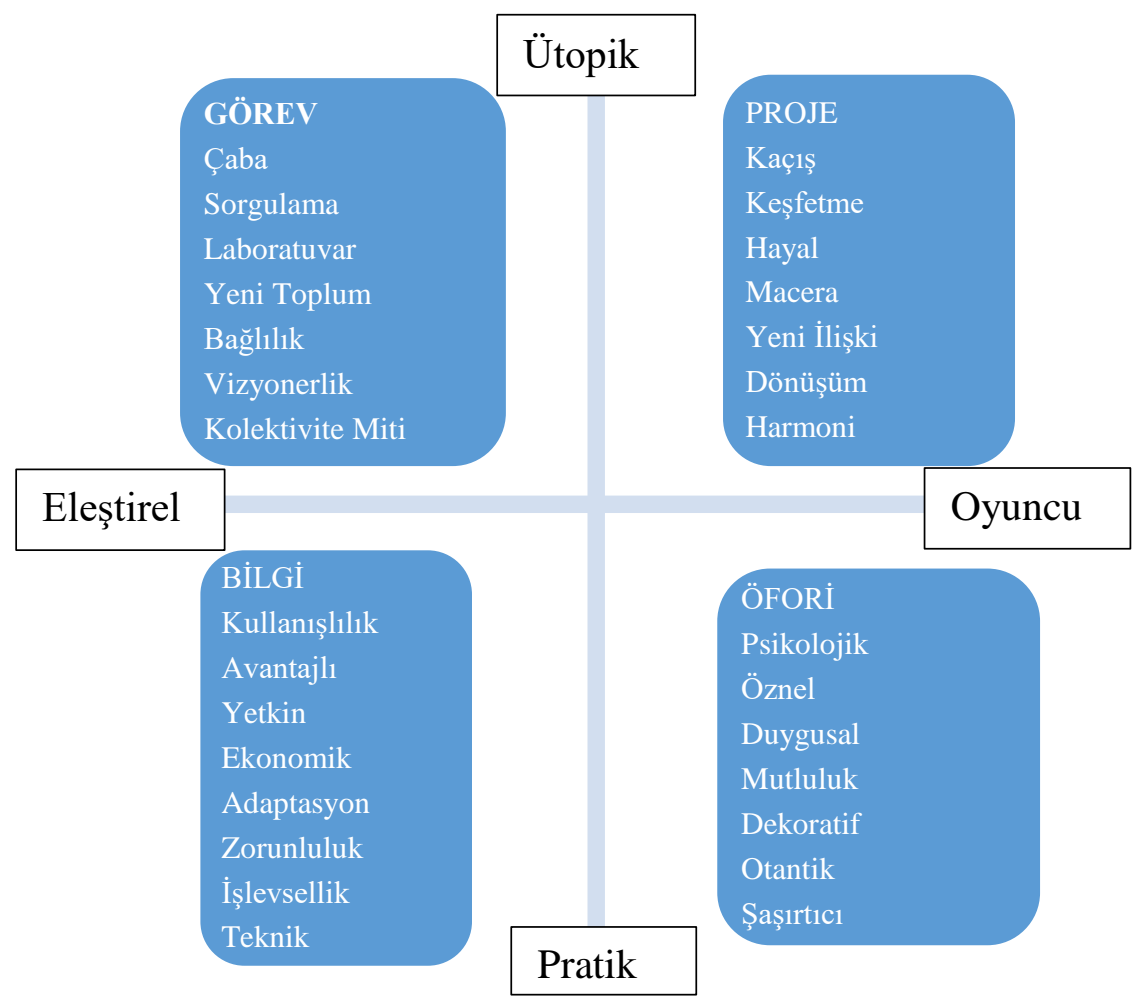

Şekil 2: İzotopi Şeması (Semprini, 1992, s. 110 ve Jeon ve Jeon, 2012, s. 982).

Gottdiener'ın toplumsal göstergebilimsel modeli yukarıdaki açıklamalar bağlamında, küresel kente yönelik, postmodern marka kent tahayyüllerinin "içerik" biçimini ve küresel kentlerin resmi web sayfalarındaki metinlerin ve izotopilerinin de "anlatım" tözünü oluşturduğunu göstererek, Şekil 3'teki biçimde uyarlanabilir. 


$$
\text { İçerik = } \begin{aligned}
& \text { Töz: Neoliberalizm / Tüketim ideolojisi } \\
& \text { Biçim: Postmodern Marka Kentler }
\end{aligned}
$$

Gösterge:

\author{
Biçim: Web Sayfaları \\ Anlatım = \\ Töz: Bilgi, Görev, Öfori, Proje Unsurlarına Bağlı Metinler
}

Şekil 3: Küresel Kentlerin Web Sayfaları Üzerinden Toplumsal Göstergebilimsel Analizi

Çalışmada, Şekil 3'te verilen göstergebilimsel modele göre göstergelerin içeriğini belirleyen postmodern marka kentler olgusuna, tüketim ideolojisiyle ilişkili olarak ilgili literatür kapsamında değinilmişti. Bu içerik, aşağıda ele alınacak metin analizinin ideolojik çerçevesini oluşturmaktadır.

Göstergelerin diğer parçası olan anlatım boyutu için ise çalışmada Şekil 2'deki dört temel alana göre küresel kentlere yönelik anlamsal inşa, web sayfalarında kullanılan tanıtım metinleri üzerinden incelenmektedir. Web sayfaları incelenecek olan küresel kentler, ele alınan örneklemi daha çeşitli oluşturabilmek için, yukarıda verilen Tablo 1, 2 ve 3'ün hepsinde (Tablo 1'deki tek listede ve Tablo 2 ve 3 'de verilmiş iki listeden en az birinde olacak şekilde) yer alan kentler olarak seçilmiştir. Çünkü bu kentler hem farklı endekslere göre küresel ilişkiler ağı içerisinde hegemonik konuma sahip hem de marka değeri yüksek kentlerdir. Buna göre incelenecek küresel/marka kentler; Londra, New York, Hong Kong, Singapur, Sydney, Paris, Dubai, Tokyo, Chicago, Moskova, Toronto, Frankfurt, Los Angeles, Madrid, Zürih, Amsterdam, San Francisco, Washington DC olarak belirlenmiştir.

Yapılacak inceleme, söz konusu kentlerin resmi belediye veya turizm sayfalarında bulunan kentleri tanıtıcı metinler arasından, kentlerin küreselliğine vurgu yapan kısımları üzerinden gerçekleştirilmiştir. Bu kapsamda öncelikle ilgili web sayfalarından kentleri tanıtıcı tüm ifadeler yazar tarafindan taranarak elde edilmiş, daha sonra özel olarak küreselliğe atıf yapmış olanlar çalışmanın örneklemi olarak ayrılmıştır. Metinlerin küresel kente atıf yapma niteliği; metin üzerinde doğrudan kentin küresel gücüne atıfta bulunulması (doğrudan "küresel" kelimesinin kullanımı ile) veya herhangi bir konuda bulunduğu bölgede/kıtada öncü konumda olduğunun belirtilmesi ile ölçülmüştür. İzotopi şemasındaki dört boyuta göre inceleme, bu parçalar üzerinde yapılmıştır. Bu incelemenin, bu kentlerdeki karar alıcıların kentlerinin küresel 
düzeyde anlamsal inşalarını hangi göstergeler üzerinden kurduklarını ortaya koymasi hedeflenmektedir.

Metinlerin incelenmesi yazar tarafindan 2020 yılı Nisan ve Mayıs aylarında sayfaların İngilizce sürümleri ${ }^{5}$ üzerinden yapılmıştır. 14 Mayıs 2020 tarihi itibarıyla metinler ayn biçimde web sayfalarında yer almaktadır. Bu metinler, genel olarak kentlerin kültürel özellikleri ve ekonomik performansları üzerine odaklanmıştır. Bu nedenle tanıtımların muhataplarının daha çok piyasa çevreleri, profesyonel hizmet sektörü çalışanları ve turistler olduğu görülmektedir.

Çalışmanın temel kısıtlılığı, genel olarak küresel kent çalışmalarının da kısttlılığ 1 ile ilişkilidir: Küresel kent çalışmaları, küresel kentlere büyük önem atfederken, küresel kent dışında kalan yerleri sermaye için daha az önemli uğrak yerleri olarak görüp göz ardı edebilmektedir (Öncü ve Weyland, 2016, s. 18). Bu çalışma da benzer bir biçimde küresel kent retoriği üzerinde durduğu için küresel kent listeleri ve kent hiyerarşilerine başvururken asıl önemi küresel kentler üzerine yüklemek, küresel olmayan kentleri ise küresel kentleri takip eden diğer kentler olarak arka plana almak zorunda kalmıştır. Bir diğer kısıtlılık, yine konusu ile ilgili olarak, çalışmanın küresel kentler için de geçerli olan neoliberalizm ve postmodernizm gibi olguları, patika bağımlı (bağlama göre biçimlenerek) olarak ortaya çıkan etkilerini (Brenner ve Theodore, 2008) göz ardı ederek, genel geçer bir biçimde ele almak zorunda kalmasidir.

\section{Seçilmiş Küresel Kentlerin Web Sayfalarındaki Metinlerin Analizi}

On sekiz kentin resmî web sayfalarında (resmi belediye ve turizm sayfaları), kentleri tanitıc bölümler arasında ilgili kentlerin küreselliğine atıf yapan metinlere ilişkin sınıflandırma Tablo 4'te gösterilmektedir. Kentin küreselliğine atıf yapan, aynı temada devam eden cümlelerden oluşan tutarlı bir metin parçası, bir frekans olarak kabul edilmiştir. Bir frekans, duruma göre birkaç cümle, bir paragraf veya birkaç paragraftan oluşmaktadır. Bu nedenle incelenen metinlerin niceliksel büyüklüğünü göstermek için değerlendirilen kelime sayısı da Tabloda gösterilmiştir. Örneğin, New York'un küreselliğine, üç farklı yerde atıf yapılmış ve toplam 191 kelime kullanılmış, Hong Kong'un

5Bu nedenle İngilizce dışındaki dillerde geçen küresel kent referansları ele alınamamış olsa da, küresel kent göstergelerinin küresel düzeyde yayılımı için uluslararası geçerliliği olan İngilizcenin seçilmesi, çalışmanın amacina uygun düşmektedir. 
küreselliğine sadece 1 yerde atıf yapılmasına rağmen 146 kelimeye başvurulmuştur.

Tablo 4: Web Sayfalarındaki Göstergelere Göre Küresel Kentler

\begin{tabular}{llll}
\hline Kent & Küreselliğe Atıf Frekansi & Kelime Sayısi & $\begin{array}{l}\text { Başvurulan Göster- } \\
\text { geler }\end{array}$ \\
\hline Londra & 14 & 1061 & Görev, Bilgi \\
\hline New York & 3 & 191 & Öfori, Bilgi \\
\hline Hong Kong & 1 & 146 & Bilgi \\
\hline Singapur & 0 & 0 & - \\
\hline Sydney & 2 & 146 & Bilgi \\
\hline Paris & 3 & 374 & Proje, Bilgi \\
\hline Dubai & 12 & 871 & Bilgi, Görev \\
\hline Tokyo & 13 & 937 & Bilgi, Görev \\
\hline Chicago & 2 & 259 & Bilgi, Öfori \\
\hline Moskova & 12 & 1236 & Bilgi, Görev \\
\hline Toronto & 9 & 1139 & Bilgi, Görev, Öfori \\
\hline Frankfurt & 4 & 504 & Bilgi, Öfori, Proje \\
\hline Los Angeles & 1 & 119 & Öfori, Proje \\
\hline Madrid & 0 & 0 & - \\
\hline Zürih & 6 & 597 & Bilgi, Öfori \\
\hline Amsterdam & 4 & 889 & Bilgi, Öfori \\
\hline San Francisco & 3 & 224 & Proje, Vizyon, Öfori \\
\hline Washington, DC & 1 & 95 & Bilgi, Öfori \\
\hline
\end{tabular}

Tabloya göre, web sayfalarındaki metinlerde küreselliğe en çok atıf yapan kentler; Londra, Tokyo, Dubai ve Moskova olmuş, metinlerin uzunluğu açısından Moskova, Toronto, Londra ve Tokyo ön plana çıkmıştır. Singapur ve Madrid kentlerinin web sayfalarındaki kentlerin tanıtım metinlerinde ise, kentlerin küreselliğine doğrudan bir atıf bulunamamıştır.

Metinlerde kullanılan ifadelere göre en çok, kentlerin kültürel ve ekonomik alanlarda avantajlarını, işlevlerini ve uygunluğunu belirten bilgi ve görev göstergelerinin kullanıldığı görülmektedir. Kentlerin küresel güçlerinin anlatıldığı metinlerde, kentler arası rekabette öne çıkan unsurları önem kazandığı için, bireysel düzeyden ziyade doğrudan kentlerin gücüne yönelik anlatımlara başvurulması beklenilen bir sonuçtur. Yine de bireysel düzeyde deneyim ve yeniliklere başvuran proje ve öfori göstergelerine de rastlanılmıştır. Aşağıda, bazı metin parçaları üzerinden göstergelerin kullanılış biçimleri örneklendirilmektedir. Parçalar içerisindeki bazı kısımlar, yazar tarafından vurgulama amacıyla altı çizili olarak gösterilmiştir. 


\section{Bilgi Göstergeleri}

Burada özellikle kentlerin küresel düzeyde kültürel ve ekonomik güçlerini doğrudan anlatan, kentin yatırımcılar, turistler ve ikamet edenleri için ne kadar işlevsel olduğunu belirten, bu bağlamda genellikle karşılaştırmalı verilerin eşlik ettiği anlatımlar öne çıkmaktadır.

Londra güzel sanatlar ve kültürün küresel bașkenti olarak tanınmış bir kenttir. Tiyatrolarımız, konser salonlarımız, müzelerimiz ve galerilerimiz dünya çapında üne sahiptir. Yaratıcı endüstrimiz Londra'nın başarısı için hayatidir ve kayıt stüdyolarımız, prova alanlarımız ve sanatçı atölyelerimiz yılda $\underline{52 \text { milyon }}$

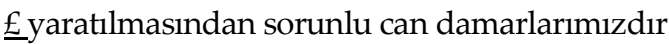

(Greater London Authority, 2020, Cultural Infrastructure Plan bölümünden alınt1).

Yukarıdaki metinde, Londra'nın kültürel alandaki küresel başarısı için kullanılan "dünya çapında üne sahip" "küresel başkent" vurgusu, kentin bu alandaki başarısına bağlanarak gösterilmektedir. Kültür endüstrisinin başarısı yaratılan mali kaynak üzerinden ölçülmektedir. Bunun yanı sıra kentin küresel başkent olarak ilanı, rakiplerinin geride bırakarak bu alanda kentler arasındaki hiyerarşinin zirvesinde olduğu bilgisini vermektedir (Nitekim Tablo 3'te verilen marka kent listelerinde Londra zirvededir). Bu metnin, kentin yetkinliğine ilişkin olduğu belirtilebilir.

Farklı bir örnek olarak, kentin küresel gücünü ve işlevsel özelliklerine ilişkin bilgi göstergeleri, ekonomik potansiyeli etrafında inşa eden Hong Kong 'u tanitıc ifadelerde bulunabilir;

Hong Kong Özel İdari Bölgesi hızlıca büyüyen Asya'da ideal konumuyla ve anakara ekonomisi tarafindan getirilen firsatlardan yararlanarak, uluslararası ticaret ve finans merkezi olmuş, aynı zamanda tanınmış bir turist kenti olarak küreselleșen dünyaya yüksek katma değerli ve bilgi yoğun hizmetler sunmuştur. Hong Kong ayrıca deniz aşırı yatırımcılar için anakaraya açılan kapı, aynı zamanda Anakara yatırımcılarının küresele açılması için bir platform olarak hizmet vermektedir.

Küçük açık ekonomi olarak Hong Kong'un işletmeler için birçok güçlü alanı vardır, basit ve düşük vergi rejimi, sermaye ve bilginin serbest dolaşımı, yüksek verimli piyasalar, dünya standartlarında altyapı, hukukun üstünlüğüne dayalı gelenek vb. hepsi ekonomik başarımızın köşe taşlarıdır. (...)

(Hong Kong Tourism Board, 2020, Welcome Message bölümünden alıntı)

Metinde kentin avantajları ve yetkinliği, coğrafi konumuna ve sermaye ile ilişkisine dayalı metaforlar yoluyla, küresel neoliberal rejime uygun sektörlere referanslarla pekiştirilerek anlatılmaktadır. Böylece kente ilişkin bilgiler, 
kentin küreselleşen dünyaya uyumlu başarılı bir örnek olduğunu belirten göstergelerle verilmektedir.

Kentlere ilişkin bilgi göstergeleri, kentlerin başarısını neoliberal rejim çerçevesinde kentin hiyerarşik üstünlüğünü inşa etmekte kullanılan, arzu edilen hâkim değerlere dayalı ifadeler üzerinden oluşturulmaktadır;

Dünya'nın Diğer Kentleriyle Kıyaslandığında Tokyo'nun Rekabet Edebilirliği ve Üstünlüğ̈̈

Tokyo Dünya çapındaki araştırma kuruluşları tarafından oluşturulan kent listelerinin hepsinde ilk sıralardadır.

Tokyo olağanüstü pazar ölçeği, küresel olarak yönetilen firmaların toplanma yeri, temel ve dakik toplu taşıma hizmeti, mükemmel kamu güvenliği, misafirperverlik ve temizliğ̣ ile bilinmektedir.

Sizi işletmenizi Tokyo'ya, sofistike piyasalar ve cazip yașam koșulları sunan kente genişletmeniz ve işletmenizi yeni inovasyonlara ve daha büyük gelişmelere yönlendirmeniz için teşvik ediyoruz.

(Tokyo Metropolitan Government, 2020, Global Financial City: Tokyo bölümünden alıntı)

Burada, Tokyo'nun üstünlüğüne atıf, doğrudan diğer kentlerle rekabet edebilirlik gücü üzerinden inşa edilmiş, kentin ideal neoliberal ideoloji içerisindeki imgesi; ekonomik göstergelerin, güvenlik, temizlik ve ideal yaşama koşulları ile birleştirilmesi sonucunda pekiştirilmiştir. Nitekim metnin son cümlesinde, kentin üstün değerlerini, kente yatırım yapabilecek işletmelere sunulmakta, kentin güvenliği, temizliği ve ideal yaşam koşulları bu kapsamda anlam kazanmaktadır.

\section{Görev Göstergeleri}

Bu kısımda kentlere ilişkin gelecek vizyonlarından örnekler verilerek, metin üzerinde hangi unsurlar üzerinden kurgulandıkları gösterilecektir. Bu ifadeler, kentlerin gelecek için ideal kurgularını ve kentler arası rekabette nasıl üstün kalabileceklerine yönelik açılamalardan oluşmaktadır.

Londra, kentin uluslararası hâkim statüsünün korunması için kentler arası rekabettin etkilerine değinmektedir:

Londra'nın Uluslararası Statüsünü Korumak

(...)

Londra firmalara cazip kalabilmek için baskı altındadır, örneğin;

- -Uluslararası finansal marketlerin daha çok düzenlenmesi için hamleler yapılmaya başlanmıştır ki bunlar Londra'nın finans sektörüne yönelik çekiciliğini etkileyebilir. 
- $\quad$-Şangay, Singapur, Cenova veya Dublin gibi Dünya kentleri, geleneksel olarak Londra'nın hâkim olduğu alanlarda Londra ile rekabet etmek için daha kararlıdır.

- Biz Londra'nın karşılaştırmalı avantajlarını arttıracak etmenlere yönelik destek olmaya ve bu durumu tehdit eden etmenlere direnmeye devam edeceğiz (Greater London Authority, 2020, Promoting London bölümünden alıntı).

Burada, Londra'ya yönelik gelecek vizyonunun, uluslararası sermayeyi çekebilmek için diğer kentlerle rekabet gücü üzerinden açıklandı̆̆ı görülmektedir. Başarılı bir kent vizyonu hâkim olma, rekabet, tehdit, avantaj kelimeleri etrafinda oluşturulmaktadır. Metin kente yüklenen görevi, sermaye çekme yarışında rakiplerini egale etmesine dayalı işaretler üzerinden göstermektedir.

Birleşik Arap Emirlikleri dünyanın en iyi küresel uluslararası firmalarına, üst düzey teknoloji konferans ve etkinliklerine ev sahipliği yaparak, Orta Doğu'da teknoloji alanında lider olarak ortaya çıkmıştır.

Dubai görüşlerini doğrudan teknoloji ve inovasyon üzerine belirlemiştir ve Emirliği lider küresel Akıllı Kente dönüştürmek için çalışmaktadır. Emirlik ayrıca küresel sürdürülebilirlik ve rekabet için çalışan Akıllı Kentler için inovasyon markası olmayı hedeflemektedir (Dubai Corporation of Tourism \& Commerce Marketing, 2020, Dubai Smart Technologies bölümünden alıntı).

Yukarıdaki metinde ise Dubai, vizyonunu, hiyerarşik bir bağlamda (liderlik), akıllı kent, sürdürülebilirlik ve rekabet etrafında çizmiştir. Bu durum, özellikle Birleşmiş Milletler Rio Zirvesinden (1992) itibaren kentlerin ajandalarının (Yerel Gündem 21) en önemli alanlarından biri olan sürdürülebilir kalkınma ve ilişkili kavramların, neoliberal ideoloji tarafından nasıl küresel rekabette üstünlük sağlayıcı gösterge olarak kullanıldığına bir örnektir.

\section{Öfori Göstergeleri}

Bu kısımda küresel kentlerin doğrudan, mutluluk, kültürel etkinliklere katılım gibi bireysel öznel deneyimlerine ilişkin göstergeler yoluyla küresel kent anlamlarını nasıl inşa ettiklerine yönelik örnekler verilecektir.

(...)Ve Frankfurt'un motifi uluslararasıysa, o aynı etrafındaki kent bölgelerinde inanılmaz tefekkür içindedir. Zaman zaman burada, odun çerçeveli binaları, dar sokakları ve geleneksel elma şarabıyla kırsal hayatın rahatlı̆̆ hâkimdir. Buna zıt olarak Frankfurt'taki en uluslararası ve belki de ayrıca en heyecanlı bölge istasyon bölgesidir. Frankfurt kenti ciddi destekleyici önlemlerle bu bölgenin küresel karakterini yükseltmektedir. 
Bir kilometre kareden daha az bir alanda, bazı çok büyük Wilheminian tarzı evlerde yüz milletten fazla insan yan yana huzur içerisinde yaşamaktadırlar. Kaldırımlardan geçenler dünyanın tüm dillerinde konuşmaktadır ve Türk, İtalyan, Hint, Çin veya Pakistan mutafı her bir köşede bulunmaktadır. Sıcak günlerde, masa ve sandalyeler birçok kafe ve restoranın önünde açıta kurulur (Tourismus+Congress GmbH Frankfurt am main, 2020, Global Village bölümünden alınt1).

Frankfurt'un gelenekselliği, çok kültürlülüğü ve huzurlu ortamı, ayrıca bunları "küresel karakteri" çevresinde yedirmesi, küresel kentte öfori deneyimi kazandırmaktadır. Bunun yanında öfori deneyimi daha hareketli bir kent kültürü anlatısına da yedirilebilir, Los Angeles'ın durumunda görüldüğü gibi;

Los Angeles büyüleyici tarihi ve zengin kültürel mirası ile trend belirleyici küresel bir metropolistir. Space Shuttle Endeavour, Walt Disney Konser Salonu, Getty Center veya sanat galerileri veya kentsel sanat olsun, LA'in kültürel cazibe merkezlerinden daha iyisi yoktur. Transformers: The Ride-3D'den efsanevi stüdyolarına, canlı gece hayatına ve ünlü tiyatro prodüksiyonlarına kadar, LA gerçekten dünyanın eğlence başkentidir. LA yemekleri Michelin-yıldızlı restoranlar ve aynı şekilde çok kültürlü mahalleleri için alkışlanmaktadır. Spor tutkunları LA'in şampiyonların kenti olduğunu bilir, bu arada aktif Angelesliler 75 millik kıyı şeridini ve yüzlerce millik bisiklet ve yürüyüş yollarını keşfedebilirler. Kişiye özel tasarımlardan vintage'a her şey için alıșveriş yapın, veya LA'in dünya standartlarında spalarında dinlenin (LA Tourism \& Convention Board, 2020, Things To Do bölümünden alint1).

Los Angeles, kent vizyonuna da uygun olarak küresel kent anlatısını, popüler kültür unsurlarına, gece hayatına, sportif imkanlarına dayalı kent deneyimi üzerinden aktarmakta, bu anlatıyı alışveriş imkanları ile bağdaştırıp en sonunda "spalarda" dinlenme ortamı ile hareketli kent hayatı söylemine kontrast oluşturmaktadır. Böylece kentin küresel kent deneyiminin bireylere yönelik her türlü imkânını sunmaya hazır olduğu gösterilmektedir.

Chicago bașka hiçbir kent gibi değildir. Mimari harikalara, dünya standartlarında müzelere, dinamik eğlence sektörüne ve dünyanın en büyük kentlerinden bekleyeceğiniz ödüllü yemek sektörüne sahibiz. Fakat biz, herhangi büyük bir kentten daha fazlasıyız - misafirperver sakinlerimiz, kapsayıc mahallelerimiz ve Orta Batı ruhu Chicago'yu ev gibi hissettiren bir kent yapmaktadir.

Kentimizi keşfedin, yapılacak şeyler bulun, seyahatinizi planlayın ve kendinize özel Chicago tarzını bulun. (...) (Choose Chicago, 2020, Welcome To The City That Feels Like Home bölümünden alıntı). 
Chicago, kentin olanakların, eğlence, mutfak gibi kültürel unsurlara dayalı öfori göstergeleriyle sunmanın yanında kentini farklı kılacak, doğrudan öznel deneyimlere hitap edecek bir hitap biçimi bulmuştur; başka hiçbir büyük kente benzemeyecek, kişiye özel Chicago'da kişilerin kendilerini evlerindeymiş gibi hissedebilmeleri durumu. Burada kent hem küreseldir ve her şeyi içerir hem de bireysel potansiyelleri ortaya çıkarır.

\section{Proje Göstergeleri}

Küresel kentler için proje göstergeleri öfori göstergelerine benzemesine (nitekim sıklıkla birlikte kullanılmaktadırlar) rağmen, bireyler için kaçış, bilinmezlik, macera, yenilik sunma boyutuna vurgu yapma açısından bir nüans vardır. Örneğin;

İnsanlar neden San Francisco'yu ziyaret ederler? Görüntüler ve manzaralar. Eşsiz etkinlikler ve dünya standartlarında mutfak. Misafirperver insanlar, farklılık ve zengin tarih.

Fakat belki de daha önemlisi, bu durum, diğer başka hiçbir şehirde olmadığg gibi farklı unsurları harmanlayıp yeni bir şeyler yaratması ile ilgili olmalıdır: bilineni alır ve onu bilinmeyenle birleștirir, insanların beklentilerini öngörülemez anlara bağlar, yerleşmiş fikirleri șașırtıcı inovasyonlarla bir araya getirir. Açıkça, San Francisco'nun cazibesi sadece herhangi bir şey değildir, ama birçok farklı șeyin birleşimidir. (...) (San Francisco Travel Association, 2020, About The San Francisco Travel Association bölümünden alıntı).

San Francisco tanıtım metninde öngörülemezlik, bilinmezlik, farklılıkların harmanlanması, öfori deneyimlerin de ötesinde, kenti ziyaret için gerekçe sunmaktadır. Kente gelecek olanlar, kendilerini neyin beklediğini tam olarak bilemeyecekler ve bu otantik macera hissi içinde kenti deneyimleyeceklerdir. Paris örneğinde olduğu gibi, bu deneyim alışveriş yapmaya da kanalize edilebilir;

120 milyondan fazla ziyaretçiyle Avrupa'nın önde gelen alışveriş merkezi olarak gösterilen Haussmann Bulvarı, kent içinde bir kenttir. Ama Rivoli Caddesindeki, Left Bank'taki veya Mafeleine'deki mağazaları da unutmayalım. Hepsi bir arada yoğunlaştırılmış olarak, tüm alıșveriş tutkularınızı karșılayabileceğiniz Paris'in canlı yansımalarıdır. Moda, güzellik, dekorasyon, serbest zaman ve eğlence sanatı, sizi bekleyen yaratıcllık denizinin buzdağının sadece görünen kısmı. (Paris Convention and Visitors Bureau, 2020, Department stores in Paris bölümünden alıntı).

Paris, sinırsız kültürel atmosferi ve tüm boyutları ile bilinemeyecek, buzdağının büyük kısmının altında kaldığı bu yaratıcılık denizi olma niteliği ile 
Avrupa'nın önde gelen, dolayısıyla küresel boyuttaki alışveriş merkezi olarak, alışveriş tutkusunu karşlamak için ideal bir ortam olarak sunulmaktadır.

\section{Sonuç}

Küresel kentlerin web sayfaları, kentlerin küresel niteliğini vurgulayan metinlerde doğrudan sermaye, turist ve nitelikli işgücü çekme yarışı nedeniyle, kentlerin küresel düzeyde fonksiyonelliklerini gösteren bilgi boyutuna ve kentlerin gelecek vizyonlarında yarının dünyasında nasıl bir konumda olacaklarını gösteren görev boyutuna yönelik ifadelere daha sık yer verseler de, bireysel deneyim ve maceralara vurgu yapan öfori ve proje boyutlarında da ifadeler yer almaktadır. Böylece bu gösterenleri ele alarak bu çalışmada işaret sistemlerinin küresel kent olmanın anlamını metinler üzerinden nasıl inşa ettikleri gösterilmiştir. Başarılı küresel kent olma halinin yan anlamları, bu göstergeler etrafında, kentlerin sermaye ile ilişkisinin başarısı üzerinden inşa edilir. Bir diğer ifadeyle, neoliberal kent politikalarının öne çıkardığı postmodern tüketim kenti, bu göstergeleri öne çıkaran temel zemindir. Bu küresel kent mitinin oluşumu sırasında; özellikle bu kentlerde daha şiddetli görülen mekânsal adaletsizlikler bu çalışmada ortaya konulan yan anlamlar içerisinde gizlenir. Küresel kentin anlamı bunlar etrafında, ideolojik arka planı gizlenerek yeniden üretilir. Bu sırada başta kentsel dönüşüm ve soylulaştırma uygulamalarıyla ilişkili yerinden edilme süreçleri yaşanmakta ve küresel kentin cazibesini korumak için gerekli yeni profesyonel hizmet sektörünün yükselişiyle beraber, niteliksiz/marjinal sektörlerde çalışanlara da artan oranda ihtiyaç duyulması nedeniyle dengesizleşen istihdam piyasaları etrafındaki toplumsal katmanlaşma biçimleri, küresel kentlerde (ve diğer kentlerde de) gittikçe hakim olmaktadır.

Resmi web sayfalarındaki bu ifadeler, kentteki karar alıcıların misyon ve vizyonlarını yansıtmaktadır. Kentler arasındaki hiyerarşik listelerin en tepesinde bulunan bu kentlerin ortaya koyduğu küresel kent anlamının, onları yakalamaya çalışan diğer kentler tarafında da arzulanan bir statü göstergesi olması, bu söylemlerin dünya çapında kentlerin vizyonu ve misyonu açısından önemini göstermektedir. Bir diğer ifadeyle, bu unsurlar dünya çapında kent yönetimlerinin ajandalarının en önemli maddeleri olmaktadır. Kentlerin yapılı çevreleri ve peyzaj düzenlemelerinden, teşvik edilen istihdam biçimlerine, kentin kültürel hayatına kadar birçok boyut, bu göstergeler etrafında yapılandırılmaktadır. Toplumsal göstergebilimin burada yapabileceği katkı, bu çalışmada metin yönüyle gösterilen ama birçok metin dışı toplumsal pratiğe 
de uygulanabilecek olan bu yöntemin, kentlerin misyon ve vizyonlarında doğrudan ortaya konulmayan, bir bakıma gizli ekonomi politik ve ideolojik arka planına, bir diğer ifadeyle neoliberalizm ile bağlantısına işaret etmektir.

Bu çalışma, küresel kent söylemlerini ideolojik arka planı ile kullanılan göstergeleriyle bir arada ele alarak küresel kent olmanın ne anlamına geldiğini ortaya koymaya çalışmış, bu kapsamda hem küresel kent literatürüne hem de toplumsal göstergebilim literatürüne bir katkı sunmuştur. On sekiz küresel kenti ele alması, çalışmanın verilerinin genelleme düzeyini yükseltmektedir. Nitekim çalışmanın amacı tek tek küresel kentler yerine genel küresel kent kavramı kapsamında kentlerin hangi göstergelere başvurduğunu ortaya koymaktı. Ama tam da bu noktada, yeni çalışmalara da gereksinim duyulduğu ortaya çıkıyor. Çünkü bu çalışma, küresel kent argümanının hegemonik ve kentleri birbirine benzetici rolü üzerinden küresel kent göstergelerinin yaygınlığını ele almıştır. Hâlbuki kentler küresel kent retoriğinin pasif alıcıları değildir, göstergeleri kendi kültürel bağlamları ile de şekillendirir. $\mathrm{Bu}$ nedenle küresel kentlerin özel olarak ve kendi aralarında nasıl farklılaştı̆̆ını da gösteren çalışmalar, küresel kent retoriğine ilişkin genel eğilimleri işaret eden bu çalışmayı tamamlayıcı nitelikte olacaktır. Çünkü küresel kent göstergelerinin, kentlerin tarihsel bağlamı ile nasıl farklı biçimlerde etkileşime girdiğini gösteren çalışmalara ihtiyaç duyulmaktadır. 


\title{
Extended Abstract
}

\section{Semantic Construction of Global Cities: A Social Semiotics Analysis on Web Pages}

$*$

\author{
Orçun Çobangil \\ ORCID: 0000-0001-8474-8646
}

Global cities have become a main topic of study since 1980s with the advent of globalization era. Depending on the existing Marxist urban literature, these studies have mainly focused on economic causes to explain the emergence of global cities and therefore global city lists have categorized cities based on economic indicators. However, the cultural dimension of being global city has also come to the fore since global cities have become the main cultural centers of the globalized world. Cities around the world have tried to follow the examples of global cities in both economic and cultural aspects in order to become one of them so that they can attract much needed investments under the principles of neoliberal regime. This fact makes the meaning of being global city important. This paper aims to study what it means to be a global city in the concept of social semiotics analysis focusing particularly on the texts used in their official/touristic web sites describing cities for investors, qualified service workers and tourists.

Bearing the aforementioned background in mind, three global city lists, that are GaWc, Saffron City Brand Barometer and Global Power City Index (GPCI), are given at first to show the most global cities in the world. Then, Gottdiener's social semiotics analysis is evaluated by referring to its theoretical backgrounds which mainly consist of the studies of Saussure, Peirce, Barthes, Baudrillard and Foucault. The analytical power of social semiotics stems from its purpose to connect the semiotics with the ideological background. Even though this study is based on the actual texts, it can also be used for the all aspects of socially constructed environment. In this context, the subject of urban semiotics is also examined as this study aims to focus on the 
urban aspects of semiotics. Urban semiotics can be studied by evaluating a city as a language or by delineating the written or visual representations about a city. Studies of urban semiotics make important contributions to critical urban studies by addressing how semiotics can be used in the social, cultural and physical production of urban spaces. Postmodern urban imaginations seem prominent in this regard.

Postmodern urban imaginations and global brand cities are examined based on the explanations of both Harvey and Zukin. It can be stated that culture is used as a visual experience by cities especially, and city visions are shaped according to this approach. The creation of the city vision in this way is made possible by the transformation from the Fordist modern industrial city to the postmodern industrial city. For this reason, the most essential elements for global city status are information-intensive high-tech sectors, trade and financial centers, and the advanced culture industry. Two brand city lists from Saffron and Resonance are given in order to show the successful cities in this regard.

Afterwards, the literature of urban semiotics analysis studying web pages as a tool is addressed. This literature review shows that papers usually aim to describe the qualities of city branding without evaluating their social background in a critical perspective. Therefore, it seems that this paper studying texts found on the web pages of global cities in a critical perspective of social semiotics can contribute to the relevant literature.

Gottdiener's diagram which examines the content and form of a signifier is used as the conceptual framework. The content refers to the ideological background (i.e. neoliberalism) of a signifier that is the postmodern urban imaginations and the visions of global brand cities which are already discussed above. The form is the text of the web pages describing cities in this case. Consequently, the main features of postmodern urban paradigm and city branding consist of the one part of the social semiotic analysis. To evaluate the form, isotopy analysis on the text can be used. Depending on the studies of Semprini and Jeon and Jeon, the following four main themes are used for this purpose: Mission, Information, Project and Euphoria. Mission refers to the main visions and future plans about a city, while Information is about the current and practical knowledge. Euphoria consists of individual experiences such as emotions and Project is about unpredictability and surprises. The eighteen cities are selected based on the criteria that they are included in the city lists shown in this paper. These cities are as follow: London, New York, Hong Kong, Singapore, Sydney, Paris, Dubai, Tokyo, Chicago, Moscow, Toronto, Frankfurt, Los Angeles, Madrid, Zurich, Amsterdam, San 
Francisco, Washington DC. The examination was carried out on the texts which promote their own cities found the official municipality or tourism pages of the cities in question. The analysis of the texts was conducted in April and May 2020 on the English versions of the pages. The texts with a special emphasis on being global were chosen out of all of the texts. For this reason, all the expressions delineating the cities were obtained from the relevant web pages, and then those who specifically referred to globalism were separated as the sample of the study.

For the form of the signifier, selected sample texts were analyzed based on the aforementioned four themes. According to the expressions used in the texts, it is seen that Information and Mission indicators are used mostly, whose meanings indicate the advantages, functions and suitability of cities in cultural and economic fields. In the texts where the global powers of the cities are explained, it is an expected result to find more references directly to the power of the cities rather than the direct references for individuals alone, as the prominent elements of the competition among the cities has gained importance. Nevertheless, there are also indicators that apply to the individual notions of experience and innovations.

Thus, this study shows that semantic systems construct the meaning of being a global city through texts. These statements on official websites reflect the missions and visions of decision makers for their cities. The side meanings of being a successful global city are built around these indicators based on the success of the relationship of cities with capital. The meaning of the global city is reproduced around them while its ideological background remains hidden.

\section{Kaynakça/References}

ABC7 News. (2012, Ocak 27). G8/NATO slogan paints Chicago as 'global crossroads'. 12 May1s 2020 tarihinde, https://abc7news.com/archive/8519054/ adresinden erişildi. Abrahamson, M. (2014). Urban sociology, a global introduction. New York: Cambridge University Press.

Alderson, A. S. ve Beckfield, J. (2004). Power and position in the world city system. American Journal of sociology, 109(4), 811-851.

Barthes, R. (2018). Çă̆daş söylenler. (5. Basım) (Tahsin Yücel Çev). İstanbul: Metis Yayınları.

Baudrillard, J. (2018). Simulakrlar ve simulasyon. (12. Basım) (Oğuz Adanır Çev.). Ankara: Doğu Batı Yayınları.

Bolchini, D., Chatterji, R., ve Speroni, M. (2009, Ekim). Developing heuristics for the semiotics inspection of websites. In Proceedings of the 27 th ACM international conference on Design of communication (p. 67-72). 
Boyne, S. ve Hall, D. (2004). Place promotion through food and tourism: Rural branding and the role of websites. Place branding, 1(1), 80-92.

Brenner, N. ve Theodore, N. (2008). Preface: From the "new localism" to the spaces of neoliberalism. Neil Brenner ve Nik Theodore. (Eds). Spaces of neoliberalism urban restructuring in North America and Western Europe içinde (s. 1-32). Oxford: Blackwell Publishing.

Brenner, N. ve Keil, R. (2016). From global cities to globalized urbanization. Richard T. LeGates ve Frederic Stout (Der). The City reader (6. Edition) içinde (s. 666-676). Oxon: Routledge.

Brenner, N. ve Schmid, C. (2015). Towards a new epistemology of the urban?. City, 19(2-3), 151-182.

Chen, X., Orum, A. M. ve Paulsen, K. E. (2018). Introduction to cities. Singapur: WileyBlackwell.

Choose Chicago. (2020). Choose Chicago. 14 Mayıs 2020 tarihinde, https://www.choosechicago.com/ adresinden erişildi.

City of Chicago. (2020). Chicago. 14 Mayıs 2020 tarihinde, https://www.chicago.gov/city/en.html adresinden erişildi.

City of Los Angeles. (2020). Los Angeles. 14 May1s 2020 tarihinde, https://www.lacity.org/ adresinden erişildi.

Dinnie, K. (2011). Introduction to the theory of city branding. Keith Dinnie. (Ed.). City branding, theory and cases içinde (s. 3-7). Londra: Palgrave Macmillan.

Dubai Corporation of Tourism \& Commerce Marketing. (2020). Visit Dubai. 14 May1s 2020 tarihinde, https://www.visitdubai.com/en adresinden erişildi.

Eco, U. (2019). Mimarlık göstergebilimi. (F. Erkman Akerson Çev.). İstanbul: Daimon Yayınları.

Explore France. (2020). Places to go /Paris. 14 May1s 2020 tarihinde, https://www.france.fr/en/paris adresinden erişildi.

Florek, M., Insch, A., ve Gnoth, J. (2006). City council websites as a means of place brand identity communication. Place Branding, 2(4), 276-296.

Florek, M. (2011). Online city branding. Keith Dinnie. (Ed.). City branding, theory and cases içinde (s. 82-90). Londra: Palgrave Macmillan.

Foucault, M. (2001). Kelimeler ve şeyler, insan bilimlerinin bir arkeolojisi. (3. Basım). (Mehmet Ali Kılıçbay Çev.). Ankara: İmge Kitabevi.

Friedmann, J. (1986). The world city hypothesis. Development and change, 17(1), 69-83.

GaWc. (2018). The World according to GaWC 2018. 12 May1s 2016 tarihinde, https://www.lboro.ac.uk/gawc/world2018t.html adresinden erişildi.

Godfrey, B. J. ve Zhou, Y. (1999). Ranking world cities: multinational corporations and the global urban hierarchy. Urban Geography, 20(3), 268-281.

Goodchild, B. (1990). Planning and the modern/postmodern debate. The Town Planning Review, 61(2), 119-137.

Gottdiener, M. (2005). Postmodern göstergeler, maddi kültür ve postmodern yaşam biçimleri. (E. Cengiz, H. Gür, A. Nur Çev.). Ankara: İmge Kitabevi. 
Gottdiener, M., Hutchison, R. ve Ryan, M. T. (2015). The new urban sociology. (5. Edtion). Boulder: Westview Press.

Gottdiener, M., Budd, L., ve Lehtovuori, P. (2016). Key concepts in urban studies. (2. Edition). Craydon: SAGE Publications.

Greater London Authority. (2020). Mayor Of London, London Assembly. 14 May1s 2020 tarihinde, https://www.london.gov.uk/ adresinden erişildi.

Harvey, D. (2016). Kent deneyimi. (E. Soğancılar Çev.). İstanbul: Sel Yayıncılık.

Harvey, D. (2019). Postmodernliğin durumu. (8. Basım). (S. Savran Çev.). İstanbul: Metis Yayınları.

Hirt, S. A. (2009). Premodern, modern, postmodern? Placing new urbanism into a historical perspective. Journal of Planning History, 8(3), 248-273.

Hong Kong Tourism Board. (2020). Discover Hong Kong. 14 May1s 2020 tarihinde, http://www.discoverhongkong.com/eng/index.jsp adresinden erişildi.

I Amsterdam. (2020). Iamsterdam. 14 Mayis 2020 tarihinde, https://www.iamsterdam.com/en adresinden erişildi.

Jeon, H. Y., ve Jeon, J. Y. (2012). A comparative study of branding cities through semiotic abalyses of the official websites os Seoul, Tokyo and Beijing. Proceedings of the 10th World Congress of the International Association for Semiotic Studies (IASS/AIS) içinde (s. 975-998). Universidade da Coruña (España / Spain).

Kearney. (2019). A question of talent: how human capital will determine the next global leaders, 2019 Global Cities Report. 12 Mayis 2020 tarihinde, https://www.kearney.com/global-cities/2019 adresinden erişildi.

Kourdis, E. (2012). Semantic isotopies in interlingual translation: Towards a cultural approach. Gramma: Journal of Theory and Criticism, 20, 105-116.

Költringer, C. ve Dickinger, A. (2015). Analyzing destination branding and image from online sources: A web content mining approach. Journal of Business Research, 68(9), 1836-1843.

LA Tourism \& Convention Board. (2020). Discover Los Angeles. 14 May1s 2020 tarihinde, https://www.discoverlosangeles.com/ adresinden erişildi.

Lagopoulos, A. P. (2019, Ekim 11). The Semiotics of urban Space. Zlatan Karajina ve Deborah Stevenson (Ed). The routledge companion to urban media and communication. 8 Mart 2020 tarihinde, https://www.routledgehandbooks.com/doi/10.4324/9781315211633-4 adresinden erişildi.

Lefebvre, H. (2017). Şehir hakkı. (2. Basım). (I. Ergüden Çev.). İstanbul: Sel Yayıncılık.

Leff, S. ve Petersen, B. (2015). Beyond the scorecard: Understanding global city rankings. The Chicago Council on Global Affairs: Chicago, IL, USA.

LeGates, R. T. ve Stout F. (2016). Introduction to part eight. Richard T. LeGates ve Frederic Stout (Der). The city reader içinde (s. 643-6749). Oxon: Routledge.

LUCIDE. (Tarih belirtilmemiş). LUCIDE project toolkit, multilingualism in urban spaces. 12 Mayıs 2020 tarihinde, https:/www.languagescompany.com/wp-content/uploads/14_1134-LUC_Toolkit_UrbanSpaces_V9_Online.pdf adresinden erişildi 
Madrid Destino Cultura Turismo y Negocio S. A. (2020). Madrid. Official tourism website. 14 Mayıs 2020 tarihinde, https://www.esmadrid.com/en adresinden erişildi.

McFarlane, C. (2017). Learning. Mark Jayne ve Kevin Ward (Ed). Urban theory, new critical perspectives içinde (s. 172-182). Cornwall: Routledge.

Míguez González, M. I. (2011). Websites and place branding for seven Galician cities: An exploratory study. Catalan journal of communication \& cultural studies, 3(2), 297304.

Mori Memorial Foundation. (2019). Global power city index 2019. 12 May1s 2020 tarihinde, http://mori-m-foundation.or.jp/english/ius2/gpci2/index.shtml adresinden erişildi.

NYC \& Company. (2020). NYC the official guide. 14 Mayıs 2020 tarihinde, https://www.nycgo.com/ adresinden erişildi.

Öktem, B. (2016). Küresel kent söyleminin kentsel mekânı dönüştürmedeki rolü: Büyükdere-Maslak aksı. H Kurtuluş (Der). İstanbul'da kentsel ayrışma. (2. Basım) içinde (s. 25-76). İstanbul: Bağlam Yayıncılık.

Öncü, A. ve Weyland, P. (2016). Giriş: Küreselleşen kentlerde yaşam alanları ve kimlik mücadeleleri. Ayşe Öncü - Petra Weyland. (Der). Mekân, kültür, iktidar, küreselleşen kentlerde yeni kimlikler (Çev. N. Şimşek, N. Uygun) (5. Basım) içinde (s. 9-39). İstanbul: İletişim Yayınları.

Paganoni, M. C. (2012). City branding and social inclusion in the glocal city. Mobilities, 7(1), 13-31.

Paris Convention and Visitors Bureau. (2020). Paris. 14 May1s 2020 tarihinde, https://en.parisinfo.com/ adresinden erişildi.

Resonance. (2018). World's best cities: A ranking of Global Place Equity. 13 May1s 2020 tarihinde, https://media.resonanceco.com/uploads/2018/11/Resonance-2019Worlds-Best-Cities-Report.pdf adresinden erişildi.

Saffron. (2019). Saffron city brand barometer 2019. 13 May1s 2020 tarihinde, https://cbb19.saffron-consultants.com/ adresinden erişildi.

San Francisco Travel Association. (2020). Sftravel. 14 Mayıs 2020 tarihinde, https://www.sftravel.com/ adresinden erişildi.

Sassen, S. (1991). The global city, New York, London, Tokyo. Princeton: Princeton University Press.

Sassen, S. (2000). Cities in a world economy, second edition. The United States of America: Pine Forge Press.

Semprini, A. (1992). Le marketing de la marque, approche sémiotique. Paris: Editions Liaisons.

Singapore Tourism Board. (2020). Visit Singapore. 14 May1s 2020 tarihinde, https://www.visitsingapore.com/en/ adresinden erişildi.

Stadt Frankfurt am Main. (2020). City of Frankfurt am main. 14 May1s 2020 tarihinde https://frankfurt.de/english adresinden erişildi.

Stadt Zürich, Kanton Zürich ve Zürich Tourismus. (2020). Official web portal of zurich. 14 Mayıs 2020 tarihinde https://www.zuerich.ch/zh/en/ adresinden erişildi. 
Stahl, G. (2010). Urban semiotics. Ray Hutchison (Ed.). Encyclopedia of urban studies içinde (s. 918-921). The United States of America: SAGE Publications.

The City of Sydney. (2020). City of Sydney. 14 May1s 2020 tarihinde https://www.cityofsydney.nsw.gov.au/ adresinden erişildi.

The City of Toronto. (2020). Toronto. 14 Mayis 2020 tarihinde, https://www.toronto.ca/ adresinden erişildi.

The Government of the Hong Kong Special Administrative Region. (2020). Hong Kong economy. 14 Mayıs 2020 tarihinde, https://www.hkeconomy.gov.hk/en/home/index.htm adresinden erişildi.

The Moscow Mayor and Moscow Government. (2020). Moscow mayor official website. 14 Mayıs 2020 tarihinde, https://www.mos.ru/en/ adresinden erişildi.

The Toronto Convention and Visitors Association. (2020). See Toronto now. 14 Mayıs 2020 tarihinde, https://www.seetorontonow.com/ adresinden erişildi.

Tokyo Convention \& Visitors Bureau. (2020). Go tokyo. 14 May1s 2020 tarihinde, https://www.gotokyo.org/en/ adresinden erişildi.

Tokyo Metropolitan Government. (2020). Tokyo metropolitan government. 14 May1s 2020 tarihinde, https://www.metro.tokyo.lg.jp/english/ adresinden erişildi.

Toneguzzi, M. (2013, Ağustos 21). Calgary ninth on global cities prosperity report. Calgary Herald. 12 Mayıs 2020 tarihinde, http://www.calgaryherald.com/business/calgary+ninth+global+cities+prosperity+report/8812487/story.html adresinden erişildi.

Tourismus+Congress GmbH Frankfurt am main. (2020). Frankfurt am Main. 14 Mayıs 2020 tarihinde, https://www.frankfurt-tourismus.de/en adresinden erişildi.

Vannini, P. (2007). Social semiotics and fieldwork: Method and analytics. Qualitative Inquiry, 13(1), 113-140.

Vanolo, A. (2017). City branding, the ghostly politics of representation in globalising cities. Croydon: Routledge.

Warschauer, M., ve Grimes, D. (2007). Audience, authorship, and artifact: The emergent semiotics of Web 2.0. Annual Review of Applied Linguistics, 27, 1-23.

Washington DC. (2020). Washington. 14 Mayıs 2020 tarihinde, https://washington.org/ adresinden erişildi.

Winfield-Pfefferkorn, J. (2005). Exploring city branding and the importance of brand image. Master of Arts in Advertising Design at the Graduate School of Syracuse University. 13 Mayss 2020 tarihinde, http://culturaldiplomacy.org/academy/pdf/research/books/nation_branding/The_Branding_Of_Cities_-_Julia_Winfield-Pfefferkorn.pdf adresinden erişildi.

Zukin, S. (2000). The cultures of cities. (6. Basim) Cornwall: Blackwell.

Zukin, S. (2010). Naked city: The death and life of authentic urban places. ABD: Oxford University Press. 